\title{
Near-Site Transportation Infrastructure Project
} Final Report 


\section{DISCLAIMER}

This report was prepared as an account of work sponsored by an agency of the United States Government. Neither the United States Government nor any agency Thereof, nor any of their employees, makes any warranty, express or implied, or assumes any legal liability or responsibility for the accuracy, completeness, or usefulness of any information, apparatus, product, or process disclosed, or represents that its use would not infringe privately owned rights. Reference herein to any specific commercial product, process, or service by trade name, trademark, manufacturer, or otherwise does not necessarily constitute or imply its endorsement, recommendation, or favoring by the United States Government or any agency thereof. The views and opinions of authors expressed herein do not necessarily state or reflect those of the United States Government or any agency thereof. 


\section{DISCLAIMER}

Portions of this document may be illegible in electronic image products. Images are produced from the best available original document. 


\title{
Near-Site Transportation Infrastructure Project Final Report
}

\author{
J. M. Viebrock and N. Mote \\ Prepared by \\ Nuclear Assurance Corporation \\ Under Contract Number DE-AC02-90CH10441
}

for the

U.S. Department of Energy

Chicago Operations Office

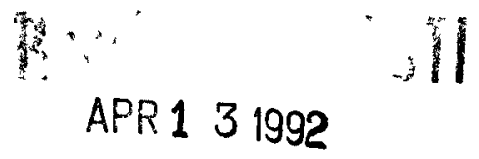

February 1992

\section{Nuclear Assurance Corporation}

6251 Crooked Creek Road Norcross, Georgia 30092

Telephone: (404) 447-1144

Telex: 6827020, 6827114

Weinbergstrasse 9

Facsimile: (404) 447-1797

8001 Zurich, Switzerland

Telephone: (01) 2617344

Telex: 817640

Facsimile: (01) 2527694

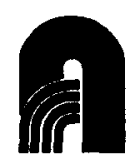

2-7-10, Sakura-Machl Mail No. 184

Koganel City, Tokyo, Japan Telephone: 423-87-6758

Facsimile: $423-87-6740$

Nuclear Assurance Corporation

Printed in the U.S.A.

NAC C-92020 - Revision 1

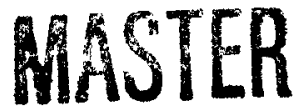




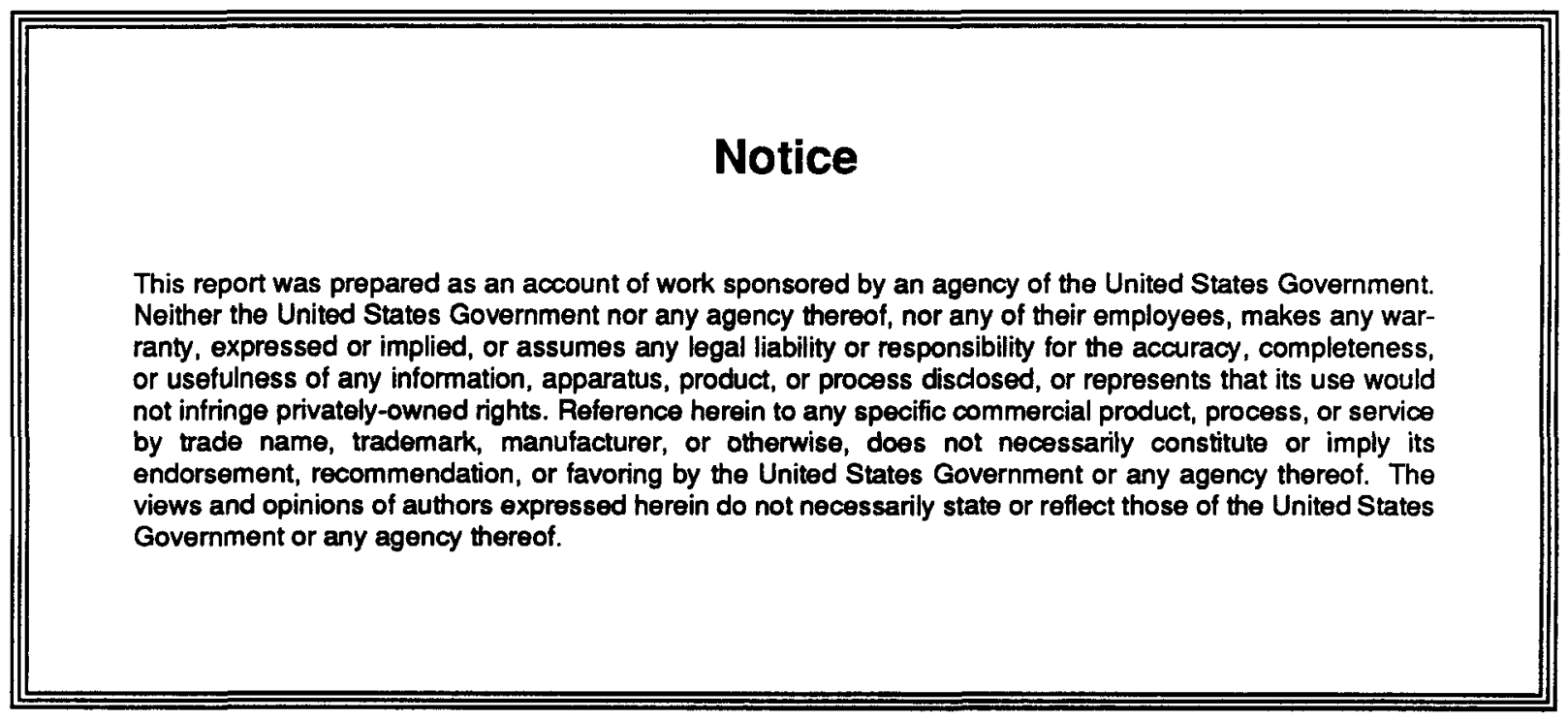

This report has been reproduced directly from the best available copy.

Available to DOE and DOE contractors from the Office of Scientific and Technical Information, P.O. Box 62, Oak Ridge, TN 37831 ; prices available from (615) 576-8401, FTS 626-8401.

Available to the public from the National Technical Information Service, U.S. Department of Commerce, 5285 Port Royal Rd., Springfield, VA 22161. 


\section{Table of Contents}

1.0 Introduction and Summary........................................................... $1-1$

2.0 Overview of the Project .................................................................. 2-1

3.0 Scope of the Project...................................................................... 3-1

3.1 Project Database ................................................................... 3-1

3.2 Data Collection ………............................................................ $3-10$

3.2.1 Road Data................................................................ $3-12$

3.2.2 Rail Facility Data........................................................ 3-14

3.2.3 Barge Facility Data .................................................. 3-14

3.3 Facility Transportation Capability Assessment Reports ........... 3-15

4.0 Results and Analysis ...................................................................... 4-1

4.1 Road Transportation Routes to the Interstate System ............. 4-1

4.1.1 Site Transportation Capability for Legal Weight Trucks

4.1.2 Site Transportation Capability for Overweight Trucks ........................................................................ 4 4-9

4.2 Site Transportation Capability for Rail Shipments .................... 4-10

4.3 Site Transportation Capability for Barge Shipments................. 4-19

4.4 Summary of Site Transportation Capability and Conclusions.. 4-26 


\section{List of Figures}

Figure

Page

4.1 Route A Road Distances to Interstate............................................ 4-7

4.2 Route B Road Distances to Interstate............................................ 4-8

4.3 Transportation Capabilities By Mode .............................................. 4-28 


\section{List of Tables}

Table

Page

$2.1 \quad$ Typical Cask Parameters …........................................................ 2-3

2.2 Typical Cask Transport Vehicle Characteristics .............................. 2-3

3.1 Site Information and Visit Schedule ................................................ $3-2$

4.1 Road Shipment Capabilities ........................................................ 4-2

4.2 Rail Shipment Capabilities........................................................ 4-11

4.3 Barge Shipment Capabilities ...................................................... 4-20 


\subsection{Introduction and Summary}

The Nuclear Waste Policy Act of 1982 (NWPA), as amended, authorizes the U.S. Department of Energy (DOE) to enter into contracts with owners and generators of high-level radioactive waste, or spent nuclear fuel (HLW/SNF), of domestic origin for acceptance of title, subsequent transportation, and disposal of such waste or spent fuel. Under the provisions of the Standard Disposal Contract (10 CFR 961) between DOE and the owners and generators of HLW/SNF, DOE is responsible for providing the shipping casks, all ancillary equipment, and transportation. The owners and generators will be responsible for loading the spent fuel into the transport casks.

The U.S. Department of Energy - Office of Civilian Radioactive Waste Management (DOE-OCRWM) is developing the Federal Waste Management System (FWMS) to accept spent nuclear fuel from commercial nuclear facilities. The FWMS encompasses a waste repository, possibly a Monitored Retrievable Storage (MRS) facility, a transportation system, hardware to support the facilities, and personnel to operate the facilities and equipment. The capabilities of the relevant commercial facility sites to ship spent-fuel casks using the three main shipping modes (road, rail and barge) will have an impact on the design and operation of the FWMS. In support of the design of the FWMS, DOE-OCRWM determined that an assessment was needed of the transportation infrastructure near the commercial facilities, taking account of both current limitations and potential upgrades.

To meet this need, DOE's Chicago Operations Office contracted with Nuclear Assurance Corporation (NAC) for the Near-Site Transportation Infrastructure (NSTI) project. The main objective of the project was to determine, for each of the 76 sites, from which spent fuel will be shipped by the FWMS, the capabilities of the existing near-site transportation networks to accommodate spent fuel shipments and to assess modal upgrade potential.

As part of the project, each of the 76 sites on which the relevant commercial nuclear facilities are located was visited to gather information first-hand and to survey the transportation infrastructure. Following completion of each survey, the existing capability of the site to ship spent fuel using road, rail and barge transportation systems was assessed, as well as the potential for upgrading. An individual assessment was then prepared, including a data base containing relevant data on each of the three transportation modes. The purpose of this final project report is to summarize the results of the individual site assessments. 
The assessments of the transportation infrastructure for each mode of transport from the sites were based on information collected during the surveys. However, the utilities and companies operating the commercial nuclear facility sites, the commercial transportation operations companies, and the state Departments of Transportation provided invaluable assistance and much of the data which could not be collected during the surveys. Cost estimates for potential upgrades to routes or transportation facilities were based on standardized costs provided by commercial transportation companies used as consultants. Where the estimated cost to refurbish or establish potential use of a transportation mode was less than $\$ 200,000$, the upgrade was assessed as possible for the terms of the NSTI project. Where the estimated cost exceeded $\$ 200,000$, the upgrade was considered as beyond the scope of the project. However, it should be noted that the scope of the project does not include the detailed technical analyses that may be required prior to implementation of some of the upgrades assessed, and is based on the judgment and engineering experience of the project staff. Thus, there is no certainty, at this stage, that the assessed upgrades could be achieved.

The NSTI project was concerned only with identifying current and potential transportation infrastructure capabilities and not with recommending which transportation mode or shipping route should be used for any of the sites assessed. Where individual routes have been identified, they were selected primarily on the basis of distance and capability as defined by the project. It is the responsibility of the shipper, carrier and the appropriate authorities to determine the mode and route for shipment of spent-fuel casks at the appropriate time. Where upgrades to transportation facilities are considered, nothing in this report is intended to indicate judgment as to whether such changes or modifications should be made. This is beyond the scope of the project. Also, nothing in this report is intended to imply that the utility or plant operator for any facility or transportation system has expressed the intention of completing the upgrades assessed.

The project reached two main conclusions. First, all sites were assessed to have the transportation infrastructure capability to ship casks on trucks which, when loaded, weigh up to at least the 40-ton "legal weight" limit. At most sites, vehicles considerably in excess of this weight could also be shipped from the site by road.

Second, all sites were assessed as having the transportation infrastructure capability to ship "rail/barge" casks weighing 100 tons or more by at least one mode of transport, if the upgrades are implemented. At many sites, casks of this type could be shipped by more than one mode. The availability of an onsite rail system provided the opportunity for direct rail shipment from 53 sites, in some cases following upgrading or extension of the existing system. At $\mathbf{4 1}$ sites the availability of or potential for developing an onsite barge facility provided the opportunity for shipment from the site by barge. In only two cases (St. Lucie and Turkey Point) was this the only means of 
transportation from the site for rail/barge casks weighing over 100 tons. However, for both of these sites, intermodal transfer facilities were identified where a rail/barge cask could potentially be off-loaded from a barge onto a railcar.

The results of the site shipping capability assessments are summarized in the following table.

\begin{tabular}{|l|l|c|c|}
\hline \multicolumn{2}{|c|}{ Transportation Infrastructure Capability by Mode } \\
\hline \multirow{2}{*}{\multicolumn{2}{|c|}{ Transportation Mode }} & \multicolumn{2}{c|}{ Number of Sites } \\
\cline { 3 - 4 } & $\begin{array}{c}\text { Current } \\
\text { Capability }\end{array}$ & $\begin{array}{c}\text { Capability if } \\
\text { Upgrades } \\
\text { Implemented }\end{array}$ \\
\hline \multirow{2}{*}{ Road } & Legal Weight & $70^{\dagger}$ & 76 \\
\cline { 2 - 4 } & Ovenweight & $72^{\dagger}$ & 75 \\
\hline \multirow{2}{*}{ Rail } & Onsite Facility & 36 & 53 \\
\cline { 2 - 4 } & Offsite Facility* & 19 & 21 \\
\hline \multirow{2}{*}{ Barge } & Onsite Facility & 17 & 41 \\
\cline { 2 - 4 } & Offsite Facility** & 1 & 2 \\
\hline
\end{tabular}

* Where an onsite rail facility exists, no offsite rail facility was assessed.

** Where an onsite rail or barge facility exists, no offsite barge facility was assessed.

$\dagger \quad$ Requirement for an "overweight" vehicle permit to ship a cask by 40 ton legal weight truck is considered an upgrade. Requirement for an "overweight" vehicle permit to ship a cask by overweight truck is regular procedure and thus not considered an upgrade. This difference results in more sites having current overweight capability than current legal weight capability.

$\ddagger \quad$ For some road routes, the upgrade would only involve load analysis. 
Section 2.0 


\subsection{Overview of the Project}

There are 122 commercial nuclear facilities from which spent nuclear fuel will be accepted by the FWMS. Since some facilities share common sites and some facilities are on adjacent sites, 76 sites were identified for the NSTI project.

The objective of the NSTI project was to identify the options available for transportation of spent-fuel casks from each of these commercial nuclear facility sites to the main transportation routes - interstate highways, commercial rail lines and navigable waterways available for commercial use. The near-site transportation infrastructure from each site was assessed, based on observation of technical features identified during a survey of the routes and facilities plus data collected from referenced information sources. The potential for refurbishment of transportation facilities which are not currently operational was also assessed, as was the potential for establishing new transportation facilities.

The project commenced in June 1989, with the initial work focusing on preparation for the start of the site visit program. The main tasks were to:

- Identify the data items to be recorded

- Create the project data base

- Develop procedures for performance of the surveys and preparation of reports

- Obtain preliminary data from identified data sources

- Set up the site visit program with the utilities and operators of the sites to be visited

During this phase of the project, technical direction and endorsement were received from DOE's Chicago Operations Office and Martin Marietta Energy Systems, Inc. at Oak Ridge National Laboratory.

The first survey was conducted in October 1989, and the survey program continued through March 1991. During the surveys, data was collected in line with the procedures developed early in the project. The facilities to be assessed were visited, and the road routes identified to the interstate system and to potential offsite rail and barge facilities were driven. Selection and characterization of the potential road routes from each site took into account prior utility experience of shipping new fuel to the site and shipping low-level waste and/or spent fuel from the site. However, while the NSTI project used this experience as valuable input, the selection of routes was based primarily on minimizing route lengths and in many cases differed from routes used previously for other purposes. 
Estimates of the cost of achieving potential upgrades to rail and barge facilities and the heavy-haul transport (HHT) routes to them were based on standard costs provided by specialized transportation consultants. The estimated cost of upgrading rail systems ranged from $\$ 50$ per foot for basic refurbishment of track on level ground by replacement of ties and ballast to $\$ 180$ per foot for installation of new track including providing fill, and significant grading of the track bed.

Following each survey a draft site transportation capability assessment report was prepared and submitted to DOE and the appropriate utility or facility operator for review and comment. Any comments provided were taken into account in preparation of the final versions of the assessment reports.

The NSTI project was concerned only with the capability of the transportation infrastructure at the commercial nuclear facilities to ship spent-fuel casks from the facility sites. It did not include an assessment of the capability for handling spent-fuel casks within the reactor buildings or spent-fuel storage facilities on the site. This was the subject of the Facility Interface Capability Assessment (FICA) project, which was being performed in parallel with the NSTI project. As the two projects are closely related, some of the results of the FICA assessments are relevant to the NSTI project and were presented for information in the NSTI site survey assessment reports.

At this stage in the development of the FWMS, the vehicles to be used for transportation of spent-fuel shipping casks to or from nuclear facility sites have not been defined, and no detailed vehicle specifications are available. Consequently, information from the FICA project was also used to develop a table of characteristics for representative transportation vehicles to be used where required as the basis of assessment for the project.

Although the NSTI project is not intended to assess transportation capabilities with respect to a defined set of casks, it is necessary to specify nominal loaded cask weights and other relevant parameters in developing the representative transportation vehicle characteristics. Table 2.1 shows the cask parameters used which are from the FICA project. 
Table 2.1

Typical Cask Parameters

\begin{tabular}{lccc}
\multicolumn{1}{c}{ Cask Types } & $\begin{array}{c}\text { Loaded Cask } \\
\text { Weight }\end{array}$ & $\begin{array}{c}\text { Cask Body } \\
\text { Diameter }\end{array}$ & $\begin{array}{c}\text { Maximum Cask } \\
\text { Length }\end{array}$ \\
\hline Legal Weight Truck & 28 tons & 3 feet, 6 inches & 17 feet, 0 inches \\
Overweight Truck & 40 tons & 4 feet, 8 inches & 17 feet, 2 inches \\
100-ton Rail/Barge & 100 tons & 7 feet, 4 inches & 17 feet, 2 inches \\
125-ton Rail/Barge & 125 tons & 8 feet, 3 inches & 17 feet, 2 inches
\end{tabular}

The legal weight truck and 100-ton rail/barge casks are representative of the casks being developed by DOE for the FWMS. The overweight truck and 125-ton rail/barge casks are representative of casks which are being considered by DOE-OCRWM but whose development has been deferred. Table 2.2 shows the vehicle characteristics used for this project which are derived from the nominal cask parameters in Table 2.1.

\section{Table 2.2}

Typical Cask Transport Vehicle Characteristics

\begin{tabular}{lcccc}
\multicolumn{1}{c}{ Vehicle Type } & Length & Width & Height & $\begin{array}{c}\text { Gross } \\
\text { Weight }\end{array}$ \\
\hline Road-Legal Weight & 65 feet & 8 feet, 6 inches & 11 feet, 4 inches & 40 tons \\
Road-Overweight ${ }^{1}$ & 65 feet & 8 feet, 6 inches & 11 feet, 4 inches & 65 tons \\
$\begin{array}{l}\text { Road-Heavy-Haul } \\
\text { Transport }\end{array}$ & $65-90$ feet & 12 feet, 0 inches & 13 feet & $\begin{array}{c}125-225 \\
\text { tons }\end{array}$ \\
$\begin{array}{l}\text { Railcar with } \\
\text { 100-ton Cask }\end{array}$ & 48 feet & 10 feet, 8 inches & 15 feet, 1 inch & 132 tons \\
$\begin{array}{l}\text { Railcar with } \\
\text { 125-ton Cask }\end{array}$ & 54 feet & 10 feet, 8 inches & 15 feet, 1 inch & 198 tons \\
Barge & 200 feet & 40 feet & NA & 750 tons
\end{tabular}

1. In practice, OWT and HHT dimensions and weights vary according to the number of axles, load distribution and axle spacing. 


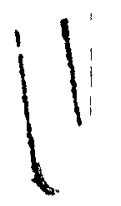

Section 3.0 


\subsection{Scope of the Project}

The main objective of the near-site transportation infrastructure project was to determine, for each of the 76 sites from which spent fuel will be shipped by the FWMS, the capabilities of the existing near-site transportation networks to accommodate spent fuel shipments and to assess modal upgrade potential. In meeting this objective, the capabilities of road routes to the Interstate system, and rail and barge facilities within a radius of approximately 25 miles of the sites, were assessed. The scope of the project included creation of the project database, preparatory data collection, a visit to each site to survey the transportation systems and preparation of individual facility transportation capability assessment reports. Table 3.1 presents information on the 76 sites, the reactor facilities on each site and the site visit schedule.

The assessments of current and potential upgrade capability were based solely on the technical requirements to ship spent fuel. For some sites, local administrative restrictions were identified which are related to the nature of the material for which routes were being identified rather than the technical characteristics of the loaded vehicles. In these cases, the restrictions were noted in the assessment reports but were not taken into account in assessing the technical capability of shipping by the transportation mode concerned.

Also, where estimates were made of the cost of achieving upgrades to existing routes or facilities, or establishing new transportation facilities, these only included the direct operational cost of completing the upgrade. They did not include any associated costs for items such as licensing action which may be required if the upgrade is to a facility on a utility site. Estimation of such costs are outside the scope of the project, although it should be noted that they may be substantial.

\subsection{Project Database}

In order to record the data collected for assessment of the shipping capabilities for each of the commercial nuclear sites, a project database was created. Following collection of the appropriate data on and the survey visit to each of the sites, the appropriate data was entered in the project database. Also following the survey visit to each site an assessment report was prepared describing the current transportation capabilities of the site and potential capabilities following upgrade.

The NSTI Database consists of a computerized Data Base Management System (DBMS) with both report and query capabilities, designed to be used in support of the NSTI project assessments and to be compatible with other data-handling systems 
site Information and Visit schedule

Site Name

tility/Operator

ARKANSAS NUCLEAR ONE ARKANSAS POWER AND LIGHT COMPANY

2 BEAVER VALLEY

DUOUESNE LIGHT COMPANY

BIG ROCK POINT

CONSUMERS POWER COMPANY

BRAIDWOOD

COMMONWEALTH EDISON

COMPANY

5 BROWNS FERRY

TENNESSEE VALLEY

AUTHORITY

6 BRUNSWICK

CAROLINA POWER LIGHT

COMPANY

7 BYRON

COMMONWEALTH EDISON

COMPANY

8 CALLAWAY

UNION ELECTRIC COMPANY

9 CALVERT CLIFFS

BALTIMORE GAS AND

ELECTRIC COMPANY

10 CATAWBA

DUKE POWER COMPANY

11 CLINTON

ILIINOIS POWER COMPANY

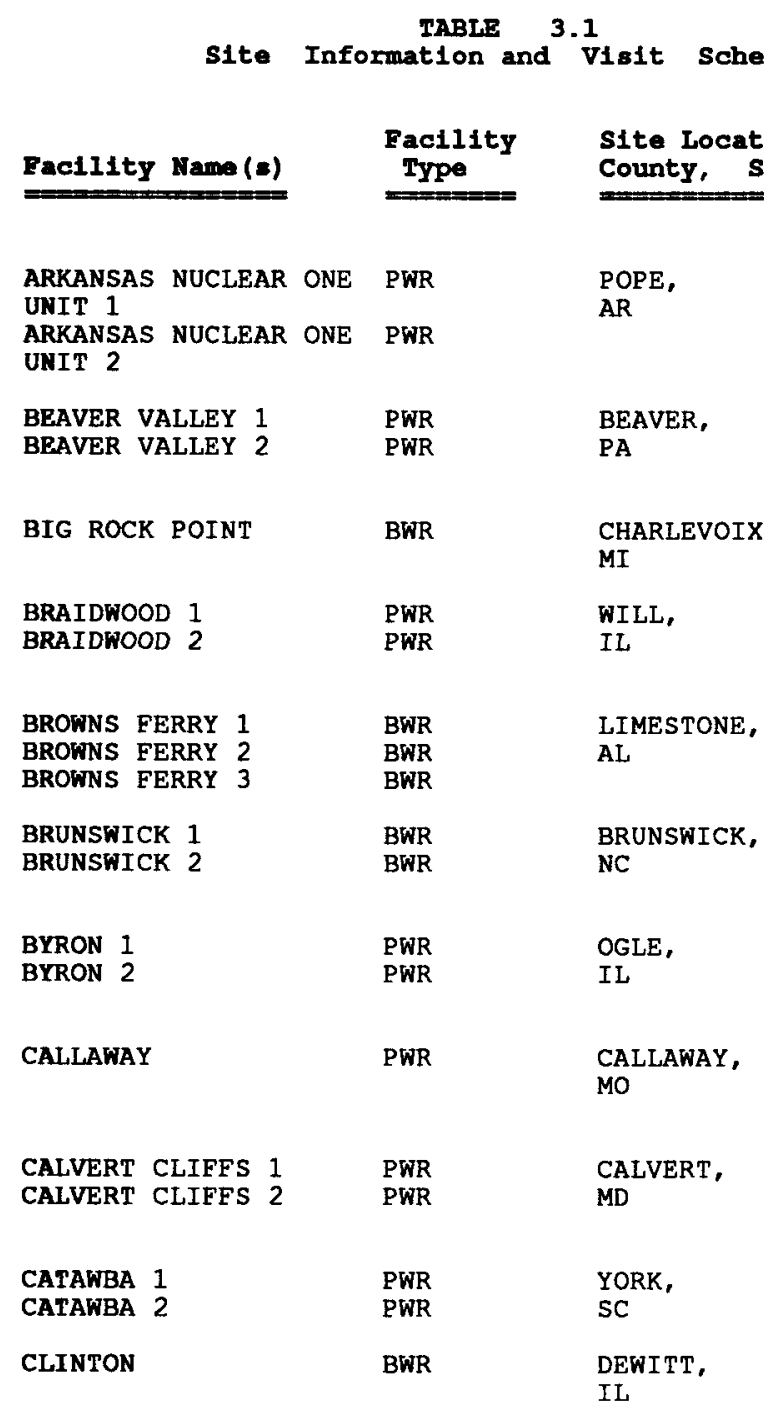

IL
Otility Contact

\section{Position}

ERANK PHILPOTT

SUPERINTENDENT, REACTOR

ROBERT D. SHERER

NUCLEAR FUEL MANAGEMENT COORDINATOR

JERRY BOSS

REACTOR ENGINEER

PATRICIA GARNIER-DAVIS SENIOR ENGINEER

JIM RATLIFF
SITE FUEL PROJECT

SITE FUEL
ENGINEER

BOB KUNITA

PRINCIPAL ENGINEER

PATRICIA GARNIER-DAVIS

SENIOR ENGINEER

AL PASSWATER

MANAGER, LICENSING \&

FUELS

KEN ALLOR

NUCLEAR ENGINEERING

SERVICES DEPARTMENT

ROBERT RASMUSSEN

SENIOR ENGINEER

BILL ILIFF

ENGI NEER
Date of

site visit

DECEMBER， 1990

NOVEMBER， 1989

OCTOBER， 1990

JULY, 1990

MARCH, 1990

MARCH, 1991

AUGUST, 1990

DECEMBER， 1990

FEBRUARY， 1991

MARCH, 1990

FEBRUARY， 1991 
TABLE 3.1 (continued)

Site Information and visit schedule

Site Site Name

Number Vtility/Operator

12 COMANCHE PEAK

TU ELECTRIC

$13 \mathrm{COOK}$

INDIANA MICHIGAN PONER

INDIANA
COMPANY

14 COOPER

NEBRASKA PUBLIC POWER

NEBRASKA

15 CRYSTAL RIVER

FLORIDA POWER

CORPORATION

16 DAVIS-BESSE

TOLEDO EDISON COMPANY

17 DIABLO CANYON

PACIFIC GAS AND ELECTRIC COMPANY

18 DRESDEN

COMMONWEALTH EDISON

COMPANY

19 DUANE ARNOLD

IOWA ELECTRIC LIGHT \&

POWER COMPANY

20 FARLEY

ALABAMA POWER COMPANY

21 FERMI

DETROIT EDISON COMPANY

22 FITZPATRICK

NEW YORK POWER AUTHORITY

\begin{tabular}{|c|c|c|}
\hline Facility Mama (s) & $\begin{array}{l}\text { Facility } \\
\text { Iype }\end{array}$ & $\begin{array}{l}\text { Site Loc: } \\
\text { County. }\end{array}$ \\
\hline $\begin{array}{l}\text { COMANCHE PEAK } 1 \\
\text { COMANCHE PEAK } 2\end{array}$ & $\begin{array}{l}\text { PWR } \\
\text { PWR }\end{array}$ & $\begin{array}{l}\text { SOMERVELI } \\
\text { TX }\end{array}$ \\
\hline $\begin{array}{l}\text { COOK } 1 \\
\text { COOK } 2\end{array}$ & $\begin{array}{l}\text { PWR } \\
\text { PWR }\end{array}$ & $\begin{array}{l}\text { BERRIEN, } \\
\text { MI }\end{array}$ \\
\hline $\begin{array}{l}\text { COOPER NUCLEAR } \\
\text { STATION }\end{array}$ & BWR & $\begin{array}{l}\text { NEMAHA, } \\
\text { NE }\end{array}$ \\
\hline CRYSTAL RIVER 3 & PWR & $\begin{array}{l}\text { CITRUS, } \\
\text { FL }\end{array}$ \\
\hline DAVIS-BESSE & PWR & $\begin{array}{l}\text { OTTAWA, } \\
\text { OH }\end{array}$ \\
\hline $\begin{array}{ll}\text { DIABLO CANYON } 1 \\
\text { DIABLO CANYON } 2\end{array}$ & $\begin{array}{l}\text { PWR } \\
\text { PWR }\end{array}$ & $\begin{array}{l}\text { SAN LUIS } \\
\text { OBISPO, } \\
\text { CA }\end{array}$ \\
\hline $\begin{array}{ll}\text { DRESDEN } & 1 \\
\text { DRESDEN } & 2 \\
\text { DRESDEN } & 3\end{array}$ & $\begin{array}{l}\text { BWR } \\
\text { BWR } \\
\text { BWR }\end{array}$ & $\begin{array}{l}\text { GRUNDY, } \\
\text { IL }\end{array}$ \\
\hline DUANE ARNOLD & BWR & $\begin{array}{l}\text { LINN, } \\
\text { IA }\end{array}$ \\
\hline $\begin{array}{ll}\text { FARLEY } & 1 \\
\text { FARLEY } & 2\end{array}$ & $\begin{array}{l}\text { PWR } \\
\text { PWR }\end{array}$ & $\begin{array}{l}\text { HOUSTON, } \\
\text { AL }\end{array}$ \\
\hline FERMI 2 & BWR & $\begin{array}{l}\text { MONROE, } \\
\text { MI }\end{array}$ \\
\hline FITZPATRICK & BWR & $\begin{array}{l}\text { OSWEGO, } \\
\text { NY }\end{array}$ \\
\hline
\end{tabular}

\section{Location: \\ ity, State}

ERVELL,

RRIEN

MAHA,

TRUS,

TAWA.

A

N

USTON,

NY
Utility Contact

Yame,

B.W. (BILL) COSS

SUPERVISOR, FUEL CYCLE MANAGEMENT

ERIC LEWIS

NUCLEAR OPERATIONS

DIVISION

PAUL BALLINGER

RNGINEERING DEPARTMENT

C.M. CALLIHAN

SENIOR NUCLEAR FUEI

MANAGEMENT ENGINEER

DR. JIM KUTCHER

SENIOR ENGINEER - NUCLEAR

DAVID L. DUKE

NUCLEAR GENERATION

ENG INEER

PATRICIA GARNIER-DAVIS

SENIOR ENGINEER

DR. WALTER NODEAN

GROUP LEADER, NUCLEAR

FUELS

BRADFORD MOORE

MANAGER OF LICENSING

SAM HASSOUN

LEAD ARCHITECT /CIVIL

ENG INEER

WILLIAM R. YARIO

SUPERVISORY ENGINEER
Date of

Dite visit

DECEMBER， 1989

FEBRUARY， 1991

FEBRUARY， 1991

NOVEMBER, 1989

MAY, 1990

JANUARY, 1991

AUGUST, 1990

JANUARY, 1991

NOVEMBER, 1989

JUNE, 1990

AUGUST, 1990 


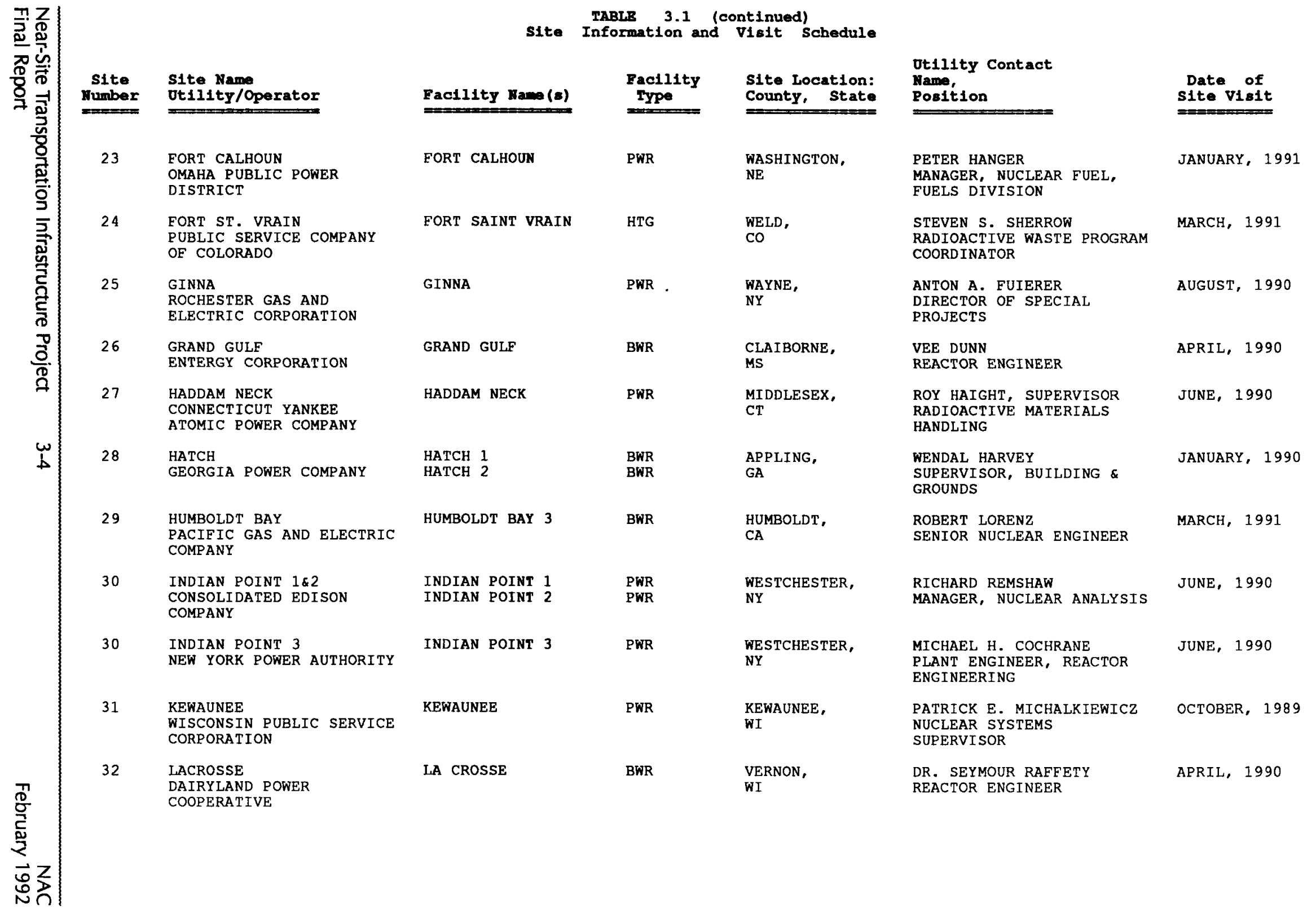


Site Site Name

Number Utility/Operator

COMMONHEATTH EDISON

COMPANY

34 LIMERICK

PHILADELPHIA ELECTRIC

35 MAINE YANKEE

MAINE YANKEE ATOMIC

POWER COMPANY

36 MCGUIRE

DUKE POWER COMPANY

37 MILLSTONE

NORTHEAST NUCLEAR ENERGY

COMPANY

38 MONTICELLO

MRTHERN STATES POWER

COMPANY

39 MORRIS

MORRIS OPERATIONS

40 NINE MILE POINT

NIAGARA MOHAWK POWER

CORPORATION

41 NORTH ANNA

VIRGINIA POWER

42 OCONEE

DUKE POWER COMPANY

43 OYSTER CREEK

JERSEY CENTRAL POWER AND LIGHT COMPANY

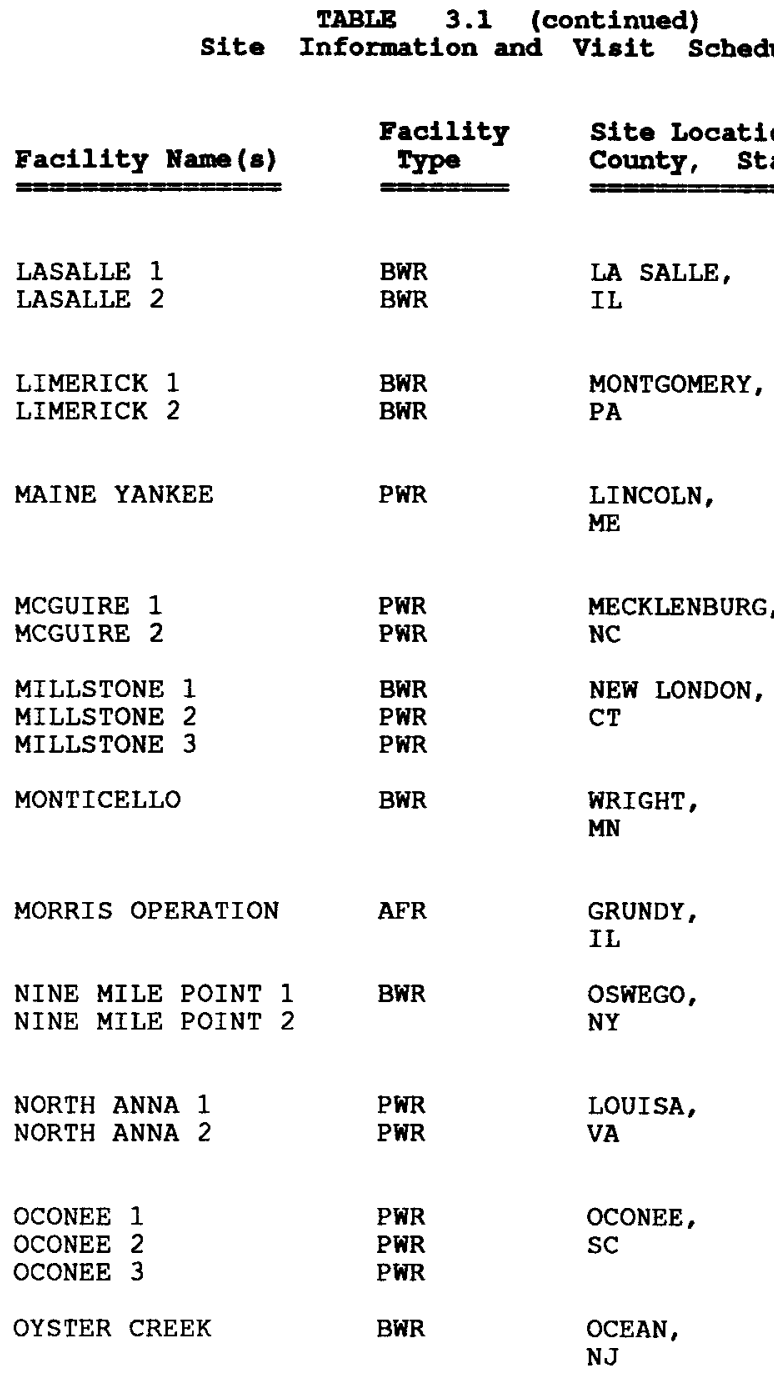

\section{Otility Contact \\ Position

Position

PATRICIA GARNIER-DAVIS SENIOR ENGINEER

WILLIAM C. BIRELY NUCLEAR SUPPORT

S. E. NICHOLS

MANAGER, NUCLEAR

ENGINEERING \& LICENSING

ROBERT RASMUSSEN

SENIOR ENGINEER

STEVE TUROWSKI

RADIOACTIVE MATERIALS

HANDIING SUPERVISOR

JOHN CLOSS

SENIOR CONSULTANT

T.E. (GENE) INGLES

PLANT MANAGER

G. K. RHODE

TRANSITION PROJECT

COORDINATOR

JOHN FISHER

STAFF TRANSPORTATION

SPECIALIST

ROBERT RASMUSSEN

SENIOR ENGINEER

RICK THOMPSON

CORE ENGINEERING MANAGER
Date of

site Visit

JULY, 1990

NOVEMBER, 1989

JUNE, 1990

MARCH, 1990

JUNE, 1990

APRIL， 1990

AUGUST, 1990

AUGUST, 1990

DECEMBER， 1989

MARCH , 1990

OCTOBER, 1989 
TABLB 3.1 (continued)

Site Information and Visit Schedule

Site Site Nam

Utility/Operator

PALISADES

CONSUMERS POWER COMPANY

45 PALO VERDE

ARIZONA PUBLIC SERVICE

46 PEACH BOTTOM

PHILADELPHIA ELECTRIC

COMPANY

7 PERRY

CLEVELAND ELECTRIC

CLEVELAND ELECTRIC

8 PILGRIM

BOSTON EDISON COMPANY

49 POINT BEACH

WISCONSIN RLECTRIC POMER

COMPANY

50 PRAIRIE ISLAND

NORTHERN STATES POWER

COMPANY

51 QUAD CITIES

COMMONWEALTH EDISON

COMPANY

2 RANCHO SECO

ACRAMENTO MUNICIPAL

UTILITY DISTRICT

53 RIVER BEND

GULF STATES UTILITIES

54 ROBINSON

CAROLINA POWER \& LIGHT COMPANY

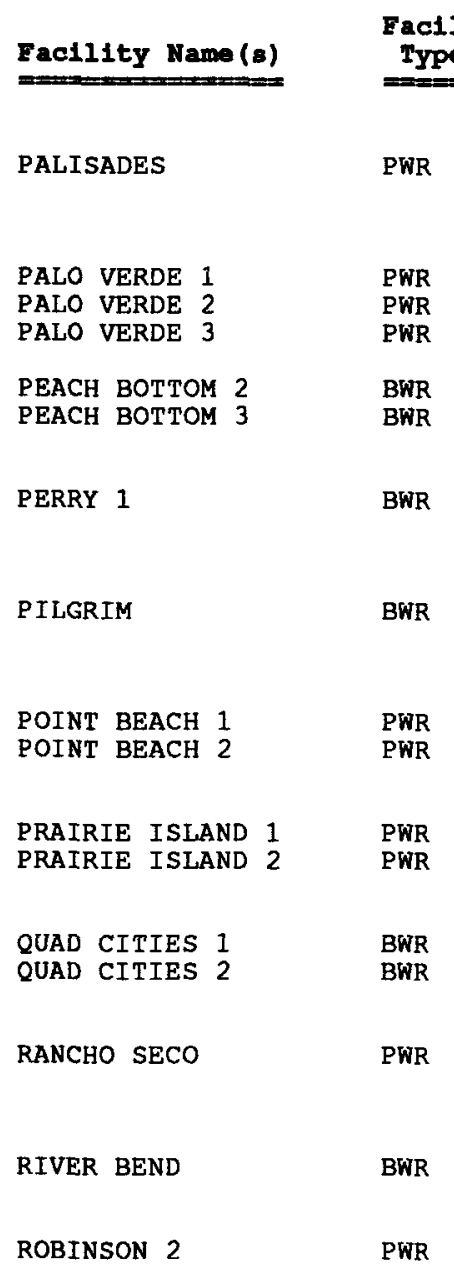

PWR

\section{Site Location: \\ County, State \\ Utility Contact \\ Name,}

VAN BUREN,

MI

GREGORY LIST

SECTION SUPERVISOR

REACTOR FUELS

MARICOPA

$A Z$

SHARON LAWSON
NUCLEAR FUEL ENGINEER

WILLIAM C. BIRELY

YORK,

$\mathrm{PA}$

LAKE,

$\mathrm{OH}$

PLYMOUTH,

MANITOWOC,

GOODHUE,

MN

ROCK ISLAND,

IL

SACRAMENTO,

$\mathrm{CA}$

WEST FELICIANA,

LAA

DARLINGTON,

MIKE MIRWALD

PUBLIC AFFAIRS

JOHN H. PIASCIK

SENIOR NUCLEAR FUEL

ENGINEER

DAVID $\mathrm{K}$. ZABRANSKY

NUCLEAR FUELS

SENIOR CONSULTANT

SENIOR ENGINEER

GREG KENEY

PRINCIPAL MECHANICAI

ENGINEER

JOHN E. BARRY

BOB KUNITA
Date of

site Visit

OCTOBER, 1990

JANUARY, 1991

OCTOBER, 1989

JUNE, 1990

OCTOBER, 1989

SENIOR PROJECT ENGINEER -

APRIL, 1990

PATRICIA GARNIER-DAVIS

AUGUST, 1990

JANUARY, 1991

SUPERVISOR, NUCLEAR FUELS

APRIL, 1990

PRINCIPAL ENGINEER
MARCH, 1991 


\section{Site Site Name \\ Number Dt1lity/Operator}

SAINT LUCIE COMPANY

56 SALEM/HOPE CREEK

PUBLIC SERVICE ELECTRIC

AND GAS COMPANY

57 SAN ONOFRE

SOUTHERN CALIFORNIA

EDISON COMPANY

58 SEABROOK

PUBLIC SERVICE

COMMISSION OF NEW

HAMP SHIRE

59 SEQUOYAH

AUTHORITY

60 SHEARON HARRIS

CAROLINA POWER \& LIGHT

CAROLINA

61 SHOREHAM

SHOREHAM

LONG ISLAN
COMPANY

62 SOUTH TEXAS PROJECT

HOUSTON LIGHTING AND

POWER COMPANY

63 SUMMER

SOUTH CAROLINA ELECTRIC

AND GAS COMPANY
TABLE 3.1 (continued)

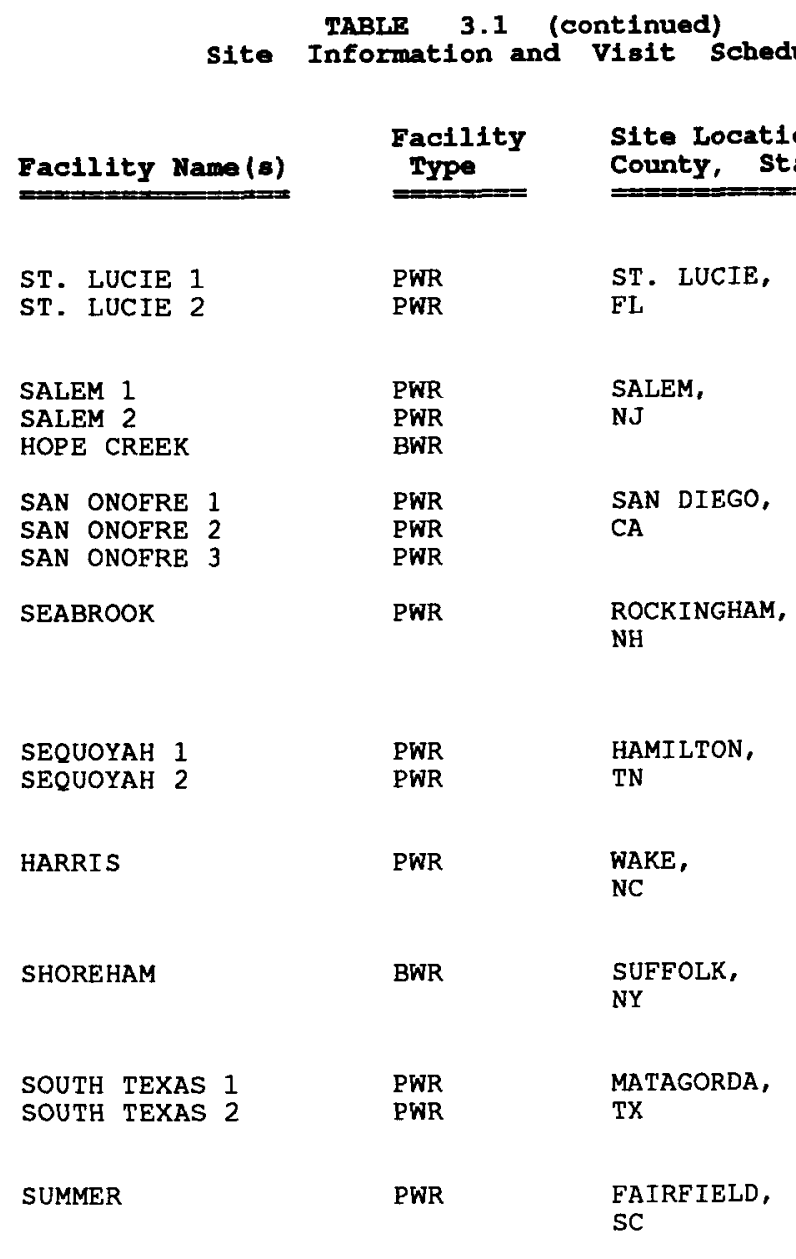

\section{otility Contact \\ Position}

JOHN A. DEMASTRY

DEPARTMENT STAFF ENGINEER

QURESH DAHODWALA

QENIOR STAFF ENGINEER

PAUL D. MYERS

MANAGER OF NUCLEAR FUEL

WALTER STURGEON

NUCLEAR SERVICES MANAGER

JANUARY, 1990

OCTOBER, 1989

JANUARY, 1991

MAY, 1990

ANDY SANISLO

SITE FUEL PROJECT

ENGINEER

BOB KUNITA

PRINCIPAL ENGINEER

SHELDON I. SCHREINER

SECTION HEAD, RADIATION

PROTECTION \& FUEL

BRIAN HANDLY

NUCLEAR FUEL ENGINEER

DOUGLAS C . WARNER

MANAGER, NUCLEAR POWER

MANAGEMENT
MARCH, 1990

MARCH, 1991

AUGUST, 1990

DECEMBER， 1989

JANUARY, 1991 
TABLE 3.1 (continued)

Site Site Name

Number Utility/Operator

Site Information and Visit schedule

64 SURRY

SURRY 2

\begin{tabular}{|c|c|c|c|}
\hline Facility Nar & $\begin{array}{l}\text { Facility } \\
\text { Type }\end{array}$ & $\begin{array}{l}\text { Site Location: } \\
\text { County, State }\end{array}$ & $\begin{array}{l}\text { Name, } \\
\text { Position }\end{array}$ \\
\hline
\end{tabular}

Jtility Contact

Date of

JOHN FISHER

PWR SURRY

STAFF TRANSPORTATION

SPECIALIST

SUSQUEHANNA 1 BWR LUZERNE

BWR
BWR

PA

DENNSYLVANIA POWER AND

Q

HOWARD R, VERNICK

PROJECT ENGINEER

DAUPHIN, JOHN A. VINCENT

NOVEMBER, 1989

66 THREE MTLE ISLAND

THREE MILE ISLAND 1 PWR DAUPHIN

GPU NUCLEAR CORPORATION

JOHN A, VINCENT

RESOURCES

67 TROJAN

COLUMBIA,

$\mathrm{OR}$

GARY BAIR

REACTOR ENGINEERING

SUPERVISOR

TURKEY POINT 3 PWR DADE

DADE
FL

FLORIDA POWER LIGHT

COMPANY

69 VERMONT YANKEE

VERMONT YANKEE NUCLLEAR

POWER CORPORATION

VERMONT YANKEE

BWR

GEORGE ZAMRY

SUPERVISOR, NUCLEAR FUEL

DEPARTMENT

WINDHAM,

H. MICHAEL METELL

PRINCIPAL ENGINEER

FEBRUARY, 1991

MARCH, 1991

JANUARY, 1990

BURKE,

VOGTLE 1
VOGTLE 2

PWR BURKE

GEORGIA POWER COMPANY

GA

CURTIS STEINSPRING

TRANSPORTATION ENGINEER

BENTON,

WASHINGTON NUCLEAR PLANT WASHINGTON PUBLIC POWER

WASHINGTON NUCLEAR

BWR

WA

DAVID L. LARKIN

MANAGER, ENGINEERING

ANALYSIS \& FUEL

ST. CHARLES

PARISH,

TIM GAUDET

LICENSING AND COMPLIANCE

LOUISIANA POWER AND

WATERFORD 3

PWR

WATTS BAR 1

PWR

RHEA,

GREG FAULKNER

REACTOR ENGINEER

MARCH， 1990

TENNESSEE VALLEY

WATTS BAR

PWR

COFFEY,

PAUL D. ADAM

REACTOR ENGINEER

DECEMBER， 1990

PERATING CORPORATION 
TABLE 3.1 (continued)

site Information and Visit Schedule

Factity Site Location

Utility/Operator

Facility Name (s) $\begin{gathered}\text { Factlity } \\ \text { Type }\end{gathered} \quad \begin{gathered}\text { Site Location: } \\ \text { County, State }\end{gathered}$

Utility Contact

Position

Date of

$===$

PWR

FRANKLIN,

RUSS MELLOR

TECHNICAL DIRECTOR, SITE

AUGUST, 1990

YANKEE ATOMIC ELECTRIC

YANKEE

MA

PATRICIA GARNIER-DAVIS

ZION 1

ZION

COMMONWEALTH EDISON

ZION 2

PWR

LAKE,

SENIOR ENGINEER

JULY, 1990 
used by DOE. In particular, the database was designed to allow data to be read into the Geographical Information System (GIS) database at the Oak Ridge National Laboratory. It was also designed to allow data to be read into the NSTI database from the FICA database and read from the NSTI database into the FICA database. This capability was incorporated to meet a perceived need to fully integrate the two databases at the appropriate time.

The NSTI database uses a Clipper ${ }^{\circledR}$ Application Program utilizing the dBase III file structure. The database was designed to be used on an MS-DOS PC and may be easily transferred between PCs using diskettes.

The number of data items in the database for each site depends on the transportation facilities available at the site and within approximately 25 miles and the lengths of the transportation routes assessed. However, there are typically five hundred data values entered in the database for each site.

\subsection{Data Collection}

In preparation for each survey, potential data sources were identified and initial information was obtained on the routes and facilities to be surveyed.

The information sources used first were typically the facility assessment reports from the FICA project and the U.S. Geological Survey 7.5 minute quadrangle maps for the area around the site. Although the FICA project did not focus on the collection of spent-fuel shipping route data, some information on site access and previous cask shipping experience was included. The other two main sources of information used in preparation for the survey visits were the utilities operating the commercial facility sites and the State Departments of Transportation.

When contact was established with the utilities to request information on the transportation systems, the utility was also invited to have a representative accompany the survey team during performance of the survey. Whether or not the utility chose to accept this invitation, the arrangements for the visit to the site were coordinated with the utility and permission was requested for the survey team to inspect and photograph the relevant transportation facilities on the utility property. Without exception, utility permission was granted and information on the transportation systems provided.

In preparing for each survey, two types of road route were considered: routes from the site to the interstate system which could be suitable for use by legal weight trucks (LWTs) or overweight trucks (OWTs); and routes to potential offsite intermodal transfer facilities which could be suitable for use by HHT vehicles. 
For all sites the objective in assessing truck shipping capability was to identify two 'primary' routes to the interstate system. Two routes were identified so that data on an alternative would be available should one of the routes become infeasible. The first preference route was designated "Route A," the second preference "Route B." The main basis for selecting these two routes was minimum distance, although other features such as avoidance of major cities or roadway quality were also considered. Where the shortest routes were not selected, the reason for the selection was identified. For some sites, additional potential routes were also identified for completeness.

The objective for assessment of rail shipping capability was to identify the best option for transportation of rail/barge casks within approximately 25 miles of the site. Where an onsite rail system existed, or could potentially be made available, within the $\$ 200,000$ limit specified for the project, no offsite facility was assessed.

The assessment focused on the identification of limitations to the shipment of rail/barge casks directly from the site by rail. Where an onsite rail capability had been provided to meet earlier shipping requirements (typically during construction) but was not currently usable, the assessment included estimating the cost of refurbishing the track. In some cases, the rail line did not extend into the cask receiving area and would thus currently require the use of an $\mathrm{HHT}$ vehicle for onsite transfer of a rail cask from the cask receiving area to railcar. Although such HHT transfer requirements would not involve the use of public highways, the additional operational requirements compared with direct loading of a cask onto a railcar in the cask receiving area would be significant. Thus, for these sites, the cost of refurbishing or extending the rail track into the cask receiving area was also estimated. In all cases the distance for which this refurbishment or installation of new track into the cask receiving area was required was less than one mile.

Where the assessment showed no potential for establishing an onsite rail shipping capability, within the $\$ 200,000$ limit specified for the project, an offsite rail facility was identified where intermodal transfer from an HHT vehicle to a railcar could potentially be performed. The existing capability of the facility, and any upgrade requirements, were assessed and a potential HHT road route from the reactor site to the transfer facility was identified.

The objective in assessing barge shipping capability was to identify the best option for transportation of rail/barge casks using an onsite barge facility, where potentially available, or an offsite facility where no onsite facility exists or could be provided within the $\$ 200,000$ limit specified for the project. 
For sites where an onsite barge facility was available or had previously existed, assessment of barge shipping capability involved identification of any dimensional or load limitations and estimation of the cost of any refurbishment required. However, the cost estimates given do not include costs for obtaining any required permits for the development of a barge capability.

For sites where no onsite barge facility was currently available or could be provided within the $\$ 200,000$ upgrade limit specified by the project, the potential use of an offsite facility was considered. Again, however, the cost estimates given do not include costs for obtaining any required permits for the development of a barge capability. Where rail shipment capability directly from the site was available or could be provided by upgrading, or where no HHT route could be identified to the barge facility within approximately 25 miles of the site, no offsite barge facility was assessed.

During the site surveys, photographs were taken to record the general characteristics of the routes and facilities surveyed. Photographs were also taken of features which represented restrictions or had particular relevance to the assessment of capabilities. These photographs were then included in the facility transportation capability assessment reports and referenced in the database.

\subsubsection{Road Data}

During the site surveys, the truck and HHT road routes identified in advance of the visit were driven and, in most cases, were confirmed as suitable routes. In some cases, however, features were identified during the visit by the survey team, or notified by the utility, which caused alternative routes to be considered in preference. During the survey, each route was considered to comprise a number of "segments." A segment was identified as a continuous part of the route with the same route number and where the following road characteristics were essentially constant:

- Number of lanes

- Lane width

- Lane separation

- Roadway condition

- Surface composition

For each segment the general characteristics of the road were recorded, including:

- Shoulder width and surface

- Level of development

- Terrain 
All key points on each segment were defined as "nodes," including at:

- Intersections

- Traffic signals or signs which affect traffic flow

- Significant changes in land width or separation

- Bridges

- Identified weight limits

- Floodplains

- Grades greater than 3 percent

- Potential intermodal transfer points

The odometer mileage was recorded at each node and general observations were recorded along the route. Following the site survey, additional information was requested from the state DOTs and other relevant agencies concerning such items as average traffic densities, accident frequencies and seasonal restrictions due to prevailing weather conditions. Any plans identified for future changes to the routes surveyed were also noted. Data related to weight limitations was requested for each route surveyed and in most cases this was related to bridges crossed by the route. However, the weight limit for most bridges depends on the configuration of the vehicle to be used and thus a single limit cannot be identified. In most states, a "legal weight" limit is defined and up to this limit there is no restriction to vehicle access unless a lower limit is posted. Above the legal weight limit, for most of the routes surveyed, vehicles are considered to "overweight" and a permit is required prior to use of the route by such vehicles. However, up to a specified overweight limit, routine permits are available depending on the vehicle configuration. For vehicles weighing above the overweight limit, the vehicle configuration and the selected route are the subject of individual analysis before a permit is issued. The legal weight limit and overweight limit for routine permits was also requested for each of the road routes surveyed.

In selecting HHT routes for potential offsite shipment of vehicles carrying rail/barge casks, any potential restrictions to the use of the routes by vehicles of weights up to 225 tons (Table 2.2) were identified. However, in most cases no weight limit was able to be determined without an individual analysis based on vehicle specification. Thus, the potential HHT routes were discussed with staff in the state DOTs on the basis of identifying any features which were likely to present restrictions based on past HHT shipment experience. Any such potential limitations were then identified in the assessment reports. 


\subsubsection{Rail Facility Data}

During the site surveys, the suitability of the identified rail facility for cask shipments was assessed and data collected to allow characterization of the track. For onsite facilities this included information to allow good representation of the rail system connecting the site to a commercial rail line and, as for the road routes, nodes were identified at key features in the rail system.

The data items recorded included:

- Owner

- Operational status

- Tie and ballast condition

- Tie spacing

- Rail dimensions (e.g., rail height, gauge)

- Number of tracks, sidings

- Clearance restrictions

- Bridges or trestles

- Weight limits

- Road crossings

- Floodplains

- Frequency of use and maintenance

- Rail company providing a commercial service

Based on this information, the current capability, and the potential capability if upgrades were implemented, were assessed. If upgrading would be needed to allow the rail system to be used, the cost of upgrading was estimated.

If intermodal transfer from an HHT vehicle to a railcar was needed, the intermodal transfer point was also characterized and the cost of any potential upgrading requirement was estimated.

\subsubsection{Barge Facility Data}

For those sites where a barge facility was identified as potentially available, the current shipping capability and the potential capability if upgraded were assessed, based on the site survey and information obtained from the appropriate utility and/or the operator of the barge facility. 
The data items recorded included:

\author{
- Owner \\ - Operational status \\ - Dimensions \\ - Water depth \\ - Installed equipment potentially available for HHT-to-barge transfer \\ operations \\ - Clearance restrictions (vertical and horizontal)
}

For those sites where a barge facility was assessed, consideration was also given to potential intermodal transfer points where a cask could be offloaded from a barge onto a railcar.

Potential barge-to-rail intermodal transfer facilities were identified but were not visited or assessed. However, major commercial facilities were identified within the near vicinity (approximately 25 miles) of the site.

\title{
3.3 Facility Transportation Capability Assessment Reports
}

Following the site survey for each site, an assessment report was prepared. This comprised a written description of the near-site transportation infrastructure and an assessment of the potential for modal upgrade where required. Handsketches of the site transportation systems and the routes assessed were included with representative photographs of the facilities and key features in the routes. The nodes identified in the road routes and the rail system were marked on the U.S. Geological Survey maps of the area as were the location of the selected rail and barge facilities.

Following preparation of the assessment report for each site as a draft, copies were provided to DOE and the appropriate utility or operating company for review and comment. Following revision to take account of any comments, a final version of each site assessment report was prepared. 


\subsection{Results and Analysis}

This section presents and summarizes the results of the transportation assessments for the 76 sites surveyed. The near-site transportation infrastructures were assessed on their ability to accommodate road, rail and barge transportation. The detailed data on which these presentations and analyses are based is recorded in the NSTI project databases for the individual sites.

For each transportation mode, the current shipping capability was assessed and any limitations were identified. Consideration was given to the potential for upgrading the routes or facilities. Each site was then assessed on its projected ability to ship if identified upgrades were implemented, and the cost of achieving these upgrades was estimated.

The current capability of each site to ship using the three transportation modes is described below. The truck transportation capability is addressed in two ways: first as it relates to legal weight shipments, and second as it relates to the potential for obtaining the permit required to allow overweight shipments to be made. In assessment of routes for LWT use, any requirement for an OWT permit below 40 tons is considered an upgrade. In assessment of routes for OWT use, any requirement for individual assessment of the vehicle and load is considered an upgrade. The number of sites able to ship via rail and barge, and the potential capabilities if upgraded, are then presented.

\subsection{Road Transportation Routes to the Interstate System}

\subsubsection{Site Transportation Capability for Legal Weight Trucks}

Table 4.1 shows on the length and assessed capability of Routes $A$ and $B$ for each of the 76 sites visited. The distribution of the route lengths is shown in Figure 4.1 for Route A and Figure 4.2 for Route B.

Route A, normally the shortest route to the interstate system, could accommodate legal weight shipments at all of the sites. The length of Route A ranged from 1.6 to 190 miles, although only three were longer than 60 miles (Diablo Canyon: 190 miles, Humboldt Bay: 166 miles and South Texas Project: 105 miles). The median length of the routes identified as Route $A$ for each site was 17.6 miles. There were six sites for which OWT vehicle permits were required for 40 -ton vehicles to use Route $A$. These sites are indicated with an asterisk in Table 4.1 in the "Capability - Legal Weight" 


\begin{tabular}{|c|c|c|c|c|c|c|c|c|c|c|}
\hline 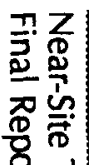 & & & & $\begin{array}{l}\text { Road } \\
\text { ROD }\end{array}$ & $\begin{array}{l}\text { TABLE } \\
\text { Shipment } \\
\text { IR A }\end{array}$ & $\begin{array}{l}4.1 \\
\text { Capabilities }\end{array}$ & & ROO & TE B & \\
\hline $7 \stackrel{3}{3}$ & & & & Capab & lity & & & Capab & ility & \\
\hline 용 & $\begin{array}{l}\text { Site } \\
\text { Number }\end{array}$ & Site Name & $\begin{array}{l}\text { Length } \\
(\mathrm{miles})\end{array}$ & $\begin{array}{l}\text { I Iegal } \\
\text { I Weight }\end{array}$ & \begin{tabular}{|c|} 
Over- \\
weight
\end{tabular} & $\begin{array}{l}\text { Overweight } \\
\text { Limit } \\
\text { (tons) }\end{array}$ & $\begin{array}{l}\text { Length } \\
\text { (miles) }\end{array}$ & $\begin{array}{l}\text { I Legal } \\
\text { | Weight }\end{array}$ & $\begin{array}{l}\text { Over- } \\
\text { Irelght }\end{array}$ & $\begin{array}{l}\text { Overwelght } \\
\text { Limit } \\
\text { (tons) }\end{array}$ \\
\hline$\frac{3}{5}$ & 1 & ARKANSAS NUCLEAR ONE & 4.9 & Yes & Yes & 54.0 & 6.5 & Yes & Yes & 54.0 \\
\hline $\overrightarrow{3}$ & 2 & BEAVER VALLEY & 32.1 & Yes & Yes & 100.5 & $\mathrm{~N} / \mathrm{A}$ & No & No & $\mathrm{N} / \mathrm{A}$ \\
\hline วิ & 3 & BIG ROCK POINT & 34.0 & Yes & Yes & 60.0 & 45.9 & Yes & Yes & 60.0 \\
\hline$\frac{5}{0}$ & 4 & BRAIDWOOD & 3.9 & Yes & Yes & 60.0 & 6.3 & Yes & Yes & 60.0 \\
\hline 꼬 & 5 & BROWNS FERRY & 16.9 & Yes & Yes & 75.0 & 15.5 & Yes & Yes & 75.0 \\
\hline$\overline{\mathrm{D}}$ & 6 & BRUNSWICK & 35.4 & Yes & Yes & 61.0 & $\mathrm{~N} / \mathrm{A}$ & No & No & $\mathrm{N} / \mathrm{A}$ \\
\hline & 7 & BYRON & 18.4 & Yes * & Yes & 60.0 & 16.1 & Yes* & No & 40.0 \\
\hline$\rightarrow$ & 8 & CALLANAY & 20.6 & Yes & Yes & 60.0 & 22.6 & Yes & Yes & 60.0 \\
\hline 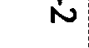 & 9 & CALVERT CLIFFS & 43.5 & Yes & Yes & 55.0 & 59.3 & Yes & Yes & 55.0 \\
\hline & 10 & CATAWBA & 13.8 & Yes & Yes & 60.0 & 25.6 & Yes & Yes & 60.0 \\
\hline & 11 & CLINTON & 13.0 & Yes & Yes & 55.0 & 19.1 & Yes & Yes & 55.0 \\
\hline & 12 & COMANCHE PEAK & 45.4 & Yes & Yes & 60.0 & 41.1 & Yes & Yes & 60.0 \\
\hline & 13 & $\mathrm{COOK}$ & 4.1 & Yes & Yes & 60.0 & 4.8 & Yes & Yes & 60.0 \\
\hline & 14 & COOPER & 9.1 & Yes* & Yes* & 65.0 & 37.5 & Yes* & Yes* & 65.0 \\
\hline & 15 & CRYSTAL RIVER & 45.4 & Yes & Yes & 60.0 & 61.7 & Yes & Yes & 60.0 \\
\hline & 16 & DAVIS-BESSE & 20.3 & Yes & Yes & 60.0 & 23.5 & Yes & Yes & 60.0 \\
\hline & 17 & DIABLO CANYON & 190.0 & Yes & Yes & $\begin{array}{c}\text { No } \\
\text { Overweight } \\
\text { Limit }^{+}\end{array}$ & 115.0 & Yes & Yes & $\begin{array}{l}\text { No } \\
\text { Overweight } \\
\text { Limit }\end{array}$ \\
\hline$\pi$ & 18 & DRESDEN & 7.0 & Yes* & Yes & 60.0 & 10.6 & Yes* & Yes & 60.0 \\
\hline $\begin{array}{l}2 \\
\vec{\omega} Z \\
\text { N }\end{array}$ & 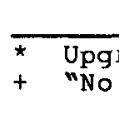 & $\begin{array}{l}\text { and/or load analy } \\
\text { erweight limit" ind }\end{array}$ & $\begin{array}{l}\text { be neede } \\
t \text { there }\end{array}$ & 10 weig & limit & cified for & shipment & Imittec & a $r$ & basi \\
\hline
\end{tabular}




\begin{tabular}{|c|c|c|c|c|c|c|c|c|c|c|}
\hline 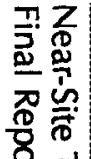 & & & & $\begin{array}{r}\text { TA } \\
\text { Road } \\
\text { ROOT }\end{array}$ & $\begin{array}{l}\text { BLS } 4.1 \\
\text { Shipmer } \\
\text { A A }\end{array}$ & $\begin{array}{l}\text { (continued) } \\
\text { Capabilities }\end{array}$ & & ROOT & $\mathbf{B} \mathbf{B}$ & \\
\hline 7 g & & & & Capab & ility & & & Capab & ility & \\
\hline$\frac{n}{8}$ & $\begin{array}{l}\text { Site } \\
\text { Number }\end{array}$ & Site Name & $\begin{array}{l}\text { Length } \\
\text { (miles) }\end{array}$ & $\begin{array}{l}\text { Legal } \\
\text { Weight }\end{array}$ & Ireight & $\begin{array}{l}\text { Limit } \\
\text { (tons) }\end{array}$ & $\begin{array}{l}\text { Length } \\
\text { (miles) }\end{array}$ & Legal & $\begin{array}{l}\text { Over- } \\
\text { weight }\end{array}$ & $\begin{array}{l}\text { Overweight } \\
\text { Limit } \\
\text { (tons) }\end{array}$ \\
\hline 奈 & 19 & DUANE ARNOLD & 11.2 & Yes & Yes & $\begin{array}{c}\text { No } \\
\text { Overweight } \\
\text { Limit }\end{array}$ & 13.1 & Yes & Yes & $\begin{array}{l}\text { No } \\
\text { Overweight } \\
\text { Limit }\end{array}$ \\
\hline 독 & 20 & FARLEY & 46.0 & Yes & Yes & 60.0 & 52.0 & Yes & Yes & 60.0 \\
\hline 동 & 21 & FERMI & 5.2 & Yes & Yes & 60.0 & 6.8 & Yes & Yes & 60.0 \\
\hline T] & 22 & FITZPATRICK & 19.0 & Yes & Yes* & 75.0 & 24.2 & Yes & Yes & 75.0 \\
\hline 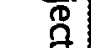 & 23 & FORT CALHOUN & 14.4 & Yes & Yes & 65.0 & 15.3 & Yes & Yes & 65.0 \\
\hline & 24 & FORT ST. VRAIN & 8.9 & Yes & Yes & 65.0 & 24.4 & Yes & Yes & 65.0 \\
\hline$\Delta$ & 25 & GINNA & 17.4 & Yes & Yes & 75.0 & 25.9 & Yes & Yes & 75.0 \\
\hline & 26 & GRAND GULF & 30.6 & Yes & Yes & 65.0 & 54.4 & Yes & Yes & 65.0 \\
\hline & 27 & HADDAM NECK & 17.9 & Yes & Yes & 70.0 & 24.5 & Yes & No & 40.0 \\
\hline & 28 & HATCH & 35.5 & Yes & Yes & 75.0 & 37.1 & Yes & Yes & 75.0 \\
\hline & 29 & HUMBOLDT BAY & 165.6 & Yes & Yes & $\begin{array}{c}\text { No } \\
\text { Overweight } \\
\text { Limit }^{+}\end{array}$ & 259.0 & Yes & Yes & $\begin{array}{l}\text { No } \\
\text { Overweight } \\
\text { Limit }^{+}\end{array}$ \\
\hline & 30 & INDIAN POINT & 19.9 & Yes & Yes & 75.0 & 20.7 & Yes & Yes & 75.0 \\
\hline & 31 & KEWAUNEE & 19.4 & Yes & Yes & 75.0 & 20.0 & Yes & Yes & 75.0 \\
\hline & 32 & LACROSSE & 51.4 & Yes & Yes & 55.0 & 23.4 & Yes & Yes & 75.0 \\
\hline & 33 & LASALLE & 14.9 & Yes & No & 40.0 & 26.1 & Yes & Yes & 55.0 \\
\hline & 34 & LIMERICK & 17.9 & Yes & Yes & 100.5 & 30.0 & Yes & Yes & 100.5 \\
\hline 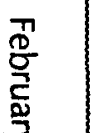 & 35 & MAINE YANKEE & 20.2 & Yes & Yes & 60.0 & 22.5 & Yes & Yes & 60.0 \\
\hline $\overrightarrow{0} \frac{Z}{3}$ & $\begin{array}{l}\overline{\text { Up }} \\
+\quad \text { "N }\end{array}$ & $\begin{array}{l}\text { and/or load } \\
\text { erweight limit }\end{array}$ & $\begin{array}{c}\text { e neede } \\
\text { there }\end{array}$ & 10 & t limi & fied & iipn & & $a$ & be \\
\hline
\end{tabular}




\begin{tabular}{|c|c|c|c|c|c|c|c|c|c|c|}
\hline 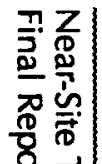 & & & & $\begin{array}{r}\text { TAI } \\
\text { Road } \\
\text { ROOTI }\end{array}$ & $\begin{array}{l}\text { Ship } 4.1 \\
\text { A }\end{array}$ & $\begin{array}{l}\text { (continued) } \\
\text { Capabilities }\end{array}$ & & Rov & E $\mathbf{B}$ & \\
\hline $\bar{g}$ & & & & Capab: & 11 ty & & & Capal & ility & \\
\hline$\frac{8}{8}$ & $\begin{array}{l}\text { Site } \\
\text { Number }\end{array}$ & S1te Name & $\begin{array}{l}\text { Length } \\
\text { (miliae) }\end{array}$ & $\begin{array}{l}\text { Legal } \\
\text { Weight }\end{array}$ & $\begin{array}{l}\text { Over- } \\
\text { welght }\end{array}$ & $\begin{array}{l}\text { Limit } \\
\text { (tons) } \\
\end{array}$ & $\begin{array}{l}\text { Length } \\
\text { (milies) }\end{array}$ & $\begin{array}{l}\text { Legal } \\
\text { Weight }\end{array}$ & $\begin{array}{l}\text { Over- } \\
\text { reight }\end{array}$ & $\begin{array}{c}\text { Limit } \\
\text { (tons) } \\
\end{array}$ \\
\hline 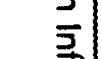 & 36 & MCGUIRE & 7.4 & Yes & Yes & 65.0 & 19.0 & Yes & Yes & 65.0 \\
\hline z & 38 & MONTICELLO & 4.2 & Yes & Yes & 54.0 & 8.8 & Yes & Yes & 54.0 \\
\hline ᄃ & 39 & MORRIS & 6.9 & Yes* & Yes & 60.0 & 10.5 & Yes* & Yes & 60.0 \\
\hline 뭉. & 40 & NINE MILE POINT & 19.6 & Yes & Yes* & 75.0 & 24.8 & Yes & Yes & 75.0 \\
\hline ๑ & 41 & NORTH ANNA & 27.0 & Yes & Yes & 57.5 & 23.3 & Yes & Yes & 57.5 \\
\hline & 42 & OCONEE & 26.2 & Yes & Yes & 65.0 & 28.7 & Yes & Yes & 65.0 \\
\hline & 46 & РЕАCH ВОТТОМ & 24.8 & Yes & Yes & 100.5 & 31.2 & Yes & Yes & 100.5 \\
\hline & 47 & PERRY & 13.6 & Yes & Yes & 60.0 & 9.9 & Yes & Yes & 60.0 \\
\hline & 48 & PILGRIM & 17.0 & Yes & Yes & 65.0 & 24.7 & Yes & Yes & 65.0 \\
\hline & 49 & POINT BEACH & 15.9 & Yes & Yes & 75.0 & 25.0 & Yes & Yes & 75.0 \\
\hline & 50 & PRAIRIE ISLAND & 36.8 & Yes & Yes & 54.0 & 42.8 & Yes & Yes & 54.0 \\
\hline & 51 & QUAD CITIES & 12.5 & Yes & Yes* & 60.0 & 16.4 & Yes* & Yes* & 60.0 \\
\hline 10 & 52 & RANCHO SECO & 33.4 & Yes & Yes & $\begin{array}{c}\text { No } \\
\text { Overweight } \\
\text { Limit }^{+}\end{array}$ & 37.4 & Yes & Yes & $\begin{array}{l}\text { No } \\
\text { Overweight } \\
\text { Limit }^{+}\end{array}$ \\
\hline ₹ & 53 & RIVER BEND & 20.5 & Yes & Yes & 106.0 & 23.2 & Yes & Yes & 106.0 \\
\hline
\end{tabular}




\begin{tabular}{|c|c|c|c|c|c|c|c|c|c|c|}
\hline 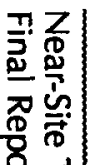 & & & & $\begin{array}{r}\text { TA } \\
\text { Road }\end{array}$ & $\begin{array}{l}\text { BI. } 4.1 \\
\text { Shipmen }\end{array}$ & $\begin{array}{l}\text { (continued) } \\
\text { Capabilities }\end{array}$ & & ROOI & E B & \\
\hline $7 \mathrm{~g}$ & & & & Capab & ility & & & Capab & ility & \\
\hline$\frac{n}{8}$ & $\begin{array}{l}\text { S1te } \\
\text { Number }\end{array}$ & S1te Ham & $\begin{array}{l}\text { Length } \\
\text { (miles) }\end{array}$ & | Iregal & Over- & $\begin{array}{l}\text { IImit } \\
\text { (tons) }\end{array}$ & $\begin{array}{l}\text { Length } \\
\text { (miles) }\end{array}$ & Wegal & Over- & $\begin{array}{l}\text { Limit } \\
\text { (tons) }\end{array}$ \\
\hline$\frac{3}{3}$ & 54 & ROBINSON & 18.3 & Yes & Yes & 60.0 & 23.2 & Yes & Yes & 60.0 \\
\hline$\stackrel{\vec{n}}{\mathfrak{n}}$ & 55 & SAINT LUCIE & 16.3 & Yes & Yes & 60.0 & 22.3 & Yes & Yes & 60.0 \\
\hline ลे & 56 & SALEM/HOPE CREEK & 22.0 & Yes & Yes & 60.0 & 22.7 & Yes & Yes & 60.0 \\
\hline $\begin{array}{l}5 \\
\overline{0} \\
0 \\
0\end{array}$ & 57 & SAN ONOFRE & 2.7 & Yes & Yes & $\begin{array}{l}\text { No } \\
\text { Overweight } \\
\text { Limit }\end{array}$ & 2.9 & Yes & Yes & $\begin{array}{l}\text { No } \\
\text { Overweight } \\
\text { Limit }^{+}\end{array}$ \\
\hline 离 & 58 & SEABROOK & 1.6 & Yes & Yes & 60.0 & 7.0 & Yes & Yes & 60.0 \\
\hline & 59 & SEQUOYAH & 20.3 & Yes & Yes & 75.0 & 24.7 & Yes & Yes & 75.0 \\
\hline$A$ & 60 & SHEARON HARRIS & 15.8 & Yes & Yes & 61.0 & 23.2 & Yes & Yes & 61.0 \\
\hline 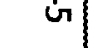 & 61 & SHOREHAM & 9.5 & Yes & Yes & 75.0 & 9.7 & Yes & Yes & 75.0 \\
\hline & 62 & SOUTH TEXAS PROJECT & 104.5 & Yes & Yes & 60.0 & 103.1 & Yes & Yes & 60.0 \\
\hline & 63 & SUMMER & 12.8 & Yes & Yes* & 65.0 & 24.2 & Yes & Yes & 65.0 \\
\hline & 64 & SURRY & 33.6 & Yes & Yes & 57.5 & 56.2 & Yes & Yes & 57.5 \\
\hline & 65 & SUSQUEHANNA & 12.0 & Yes & Yes & 100.5 & 21.0 & Yes & Yes & 100.5 \\
\hline & 66 & THREE MILE ISLAND & 8.1 & Yes & Yes & 100.5 & N/A & No & No & $\mathrm{N} / \mathrm{A}$ \\
\hline & 67 & TROJAN & 12.7 & Yes & Yes & 100.0 & 40.9 & Yes & Yes & 100.0 \\
\hline & 68 & TURKEY POINT & 45.9 & Yes* & No & 33.0 & 37.1 & Yes* & No & 33.0 \\
\hline & 69 & VERMONT YANKEE & 12.0 & Yes & Yes & $\begin{array}{l}\text { No } \\
\text { Overweight } \\
\text { Limit }\end{array}$ & 7.9 & Yes & Yes & $\begin{array}{l}\text { No } \\
\text { Overweight } \\
\text { Limit }^{+}\end{array}$ \\
\hline$\frac{\mathbb{1}}{\frac{1}{2}}$ & 70 & VOGTLE & 29.0 & Yes & Yes & 75.0 & 45.5 & Yes & Yes & 75.0 \\
\hline $\overrightarrow{0} Z$ & $\begin{array}{l}\text { * Upc } \\
+\quad \text { NC }\end{array}$ & $\begin{array}{l}\text { and/or load anal } \\
\text { rweight limit" in }\end{array}$ & $\begin{array}{l}\text { e neede } \\
\text { there }\end{array}$ & no $\mathrm{w}$ & limit & ified & & & $a$ & $b$ \\
\hline
\end{tabular}




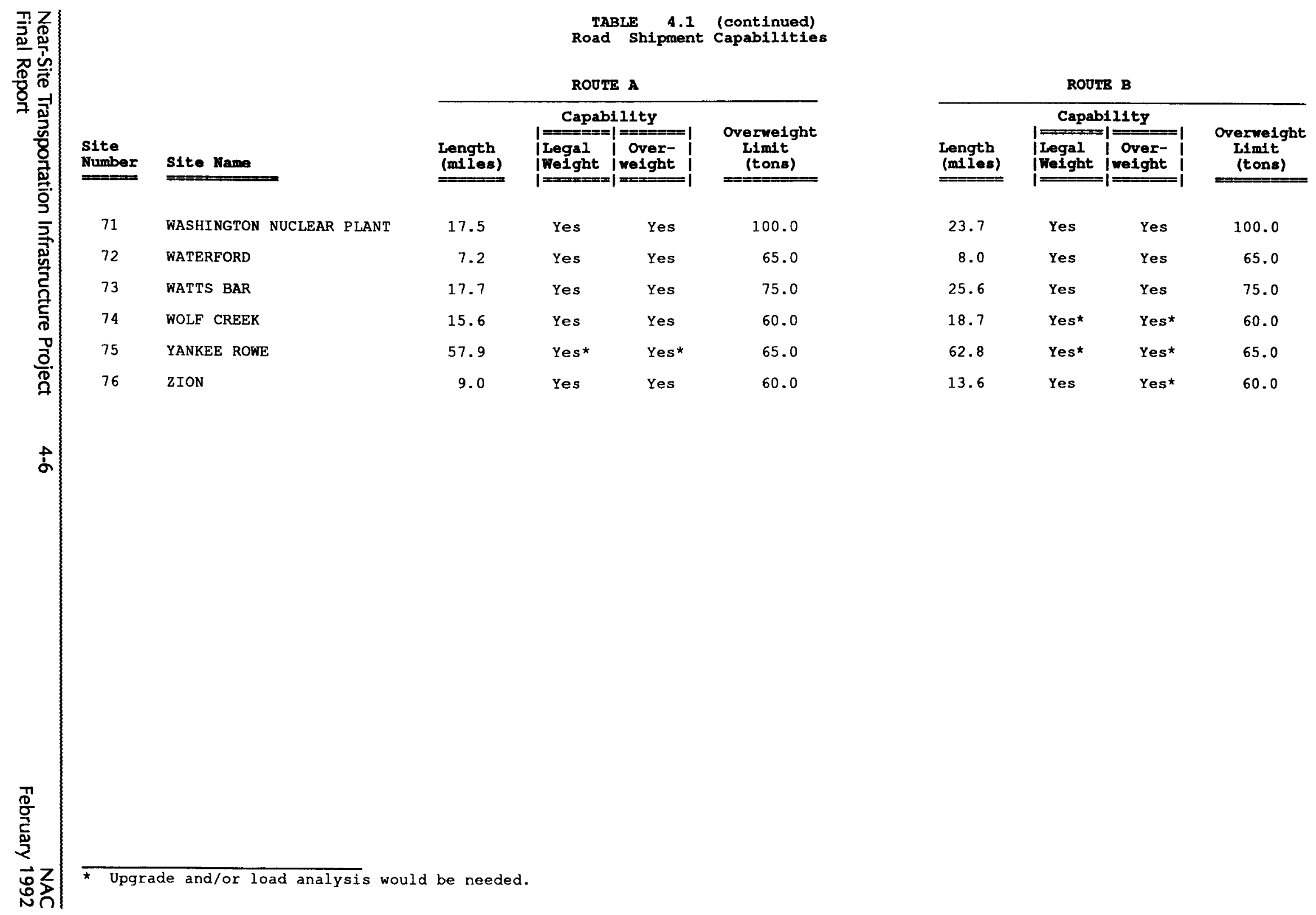


Figure 4.1

Route A Road Distances to Interstate

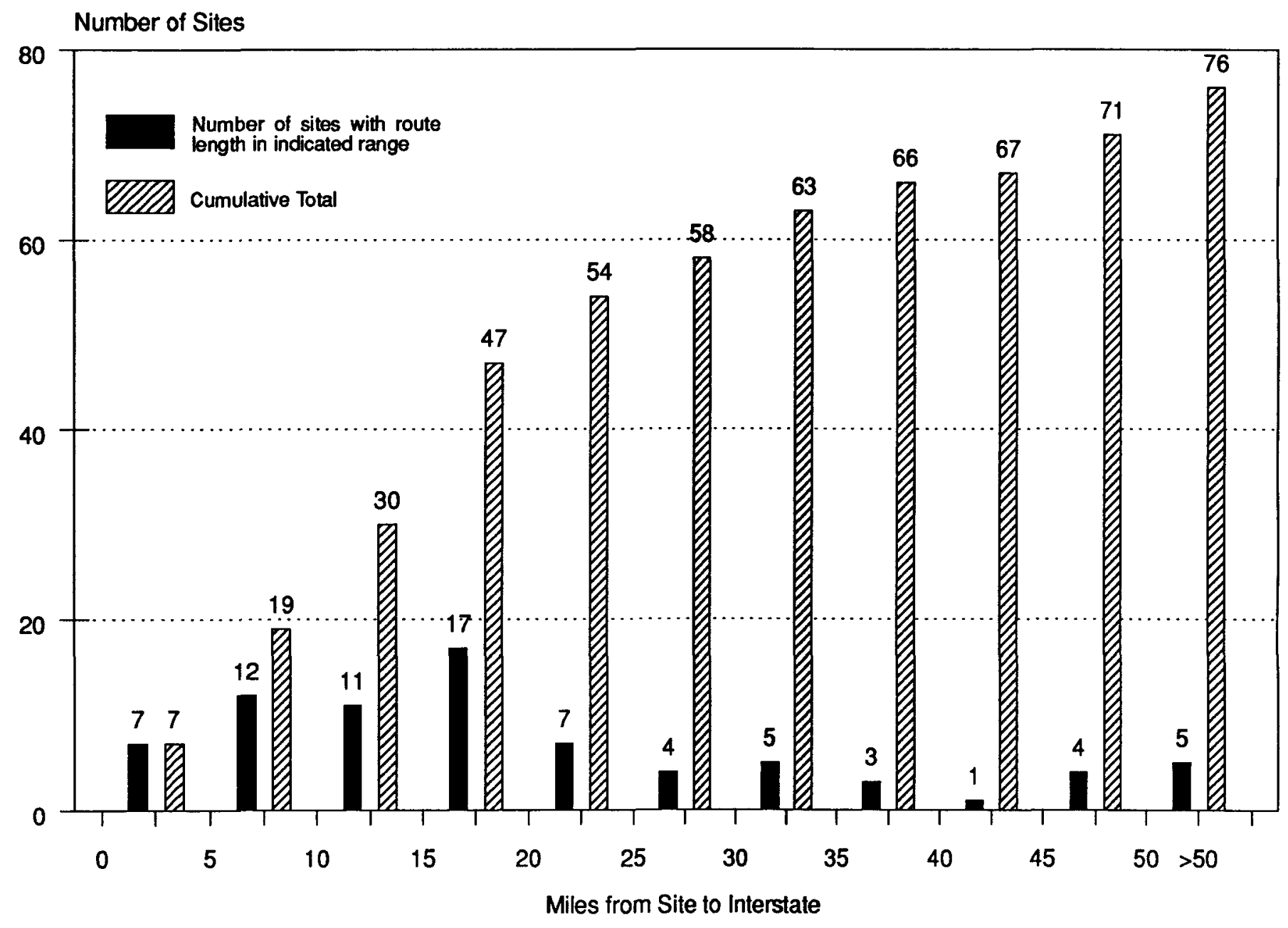


Figure 4.2

Route B Road Distances to Interstate

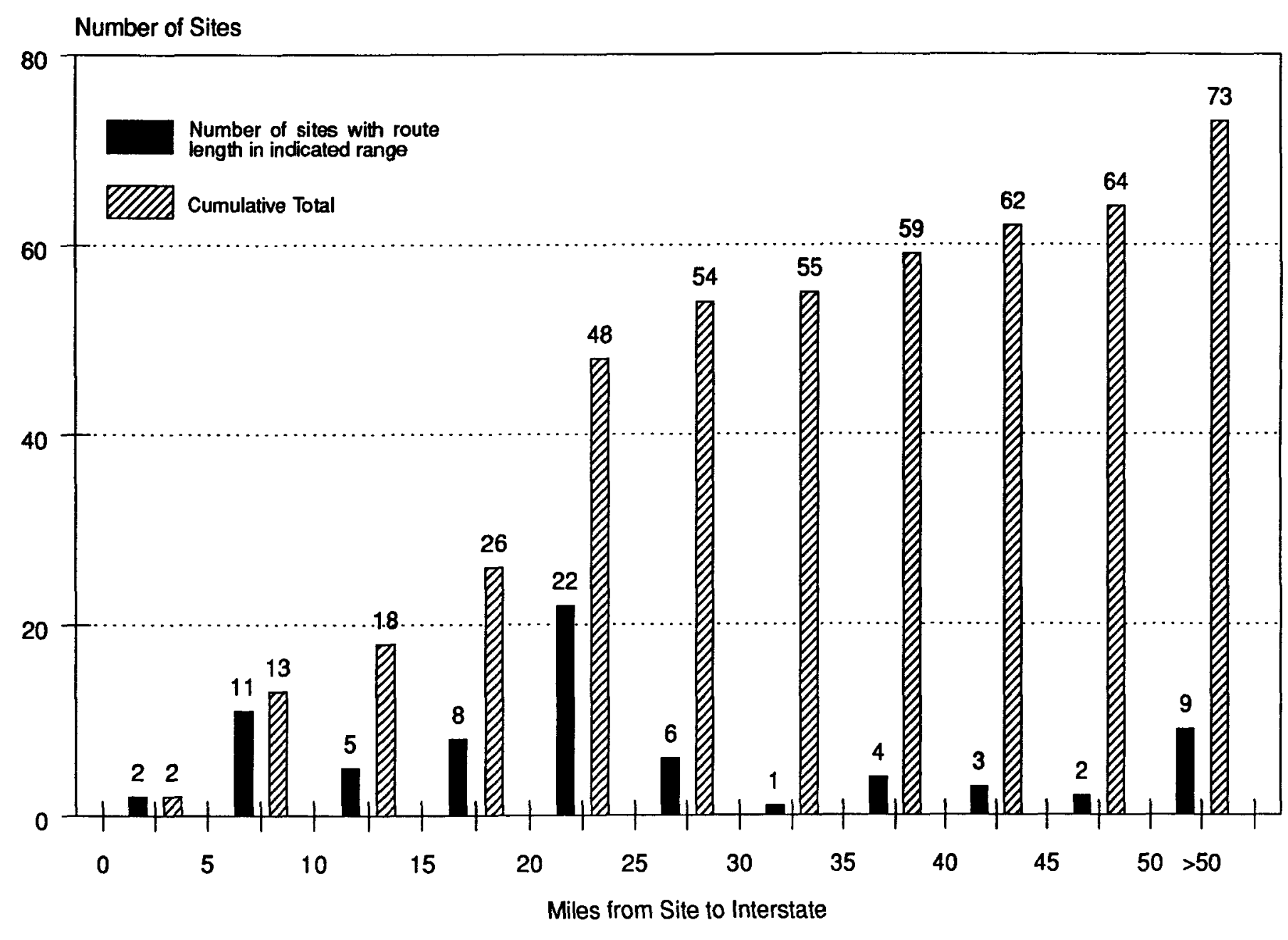


column under "Route A." For all of these sites except Turkey Point, vehicles weighing over 40 tons could also be permitted while for Turkey Point, the maximum load which would be permitted by the State DOT on the only route from the site is 40 tons.

There were 64 sites for which an alternative route to the interstate system, Route B, was identified and could currently be used for legal weight shipments. Nine additional sites had a Route $B$ identified for which OWT vehicle permits were required in order to accommodate 40-ton shipments. These sites are indicated with an asterisk in Table 4.1 in the "Capability - Legal Weight" column under "Route B." For all of these sites except Turkey Point, vehicles weighing over 40 tons could also be permitted, while for Turkey Point the maximum load permitted on the only route from the site is 40 tons as noted above. For the remaining three sites, Beaver Valley, Brunswick and Three Mile Island, no suitable Route B was identified. The length of Route B ranged from 2.9 to 259 miles, with a median length of 22.7 miles.

Three sites have identified routes that are unusually long due to the remote location of the site: Humboldt Bay, Diablo Canyon and South Texas Project. In each case, however, portions of the identified routes are constructed to interstate standards.

At 12 of the sites with an identified Route B, Route A was longer than Route B. Nine of these sites have differences in the route lengths of less than five miles. The remaining three, Diablo Canyon, LaCrosse and Turkey Point, have differences greater than five miles. There were two reasons for identifying a Route $A$ which was longer than Route B: either a portion of the longer route is constructed to interstate standards or the route avoids areas of major development.

\subsubsection{Site Transportation Capabllity for Overweight Trucks}

Routes $A$ and $B$ were also assessed for their capability to accommodate overweight shipments, and the overweight limit for each of the assessed routes is shown in Table 4.1. The maximum vehicle weight for which an overweight permit may be issued is dependent on the vehicle length, number of axles, axle spacing and individual axle loadings. The overweight limit presented in Table 4.1 is for an optimally configured overweight vehicle. It should be noted that Routes $A$ and $B$ have different overweight limits for some sites because the routes pass through areas regulated by different administrative jurisdictions.

There were 68 sites which could currently accommodate overweight shipments using the identified Route $A$. Of the eight sites which could not currently accommodate OWT vehicles on Route A, four could currently accommodate OWT vehicles on Route B. Thus, a total of 72 sites could currently accommodate OWT vehicles on at least one route. Six additional sites could accommodate overweight shipments on Route $A$ if identified upgrades were implemented. These six sites are indicated with an asterisk in Table 4.1 in the "Capability - Legal Weight" column under Route A. The 
remaining two sites, LaSalle and Turkey Point, could not accept overweight shipments on Route A. With these two exceptions, overweight limits ranged from 54 tons to above 100 tons. Turkey Point, as mentioned previously, has limited load-bearing capability along a portion of the route, and LaSalle has one bridge along the route whith a maximum load-bearing capability of 40 tons.

Sixty-four sites have an identified Route B which could currently accept overweight shipments. Six additional sites could accept overweight shipments on Route B if an identified upgrade were implemented. The remaining six sites - Beaver Valley, Brunswick, Byron, Haddam Neck, Three Mile Island and Turkey Point - fall into three groups. Three of these sites, Beaver Valley, Brunswick and Three Mile Island, have no identified Route B; two sites, Byron and Haddam Neck, have identified bridge limits; and Turkey Point has a load-bearing limit as discussed above.

In all cases, overweight shipments require permitting for loads in excess of the legal weight limit and permits are issued routinely up to the specified overweight limit. In many cases, it is possible to haul loads with a gross vehicle weight limit higher than the specified overweight limit after individual review by the state permitting office of the load/axle configuration and the specific route to be used.

\subsection{Site Transportation Capability for Rail Shipments}

Table 4.2 presents the rail shipping capability for each site, identifies the transportation mode to be used for heavy loads to access commercial rail service and records the distance from the site to the commercial rail service. The ability to move heavy loads by rail only relates to the shipment capability from the site. It does not imply that a rail/barge cask could be handled and loaded within the facility but only that the local transportation infrastructure could accommodate such a load.

Of the 76 sites surveyed, 53 have the ability to use onsite rail for the transportation of heavy loads. The onsite rail systems at $\mathbf{3 6}$ sites are currently usable, although twelve of these 36 sites currently have no rail access to the cask receiving area and onsite transfer of casks by HHT vehicle to a railcar would be required. The remaining 17 sites with potential onsite rail shipment capability have rail systems which would require upgrading prior to use. The average cost of these upgrades was estimated at $\$ 65,000$. The work required ranged from performing minor refurbishment such as the clearing of asphalt from tracks to complete replacement of sections of track.

As discussed in Section 3.0, the potential for providing rail service where none currently exists was determined based on an estimate of the required cost of upgrading. If a rail system could not be made usable for less than $\$ 200,000$, the site was not considered able to be upgraded. 
$\begin{array}{ll}\text { TABLE } & 4.2 \\ \text { Rail Shipment } & \text { Capabilities }\end{array}$

site

Rail

To Cask

Number

Site Name

Service

Recelving

Rail

Facility

Access to Commercial
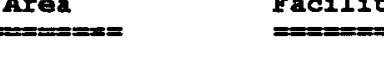

1 ARKANSAS NUCLEAR ONE

Yes

Yes

2 BEAVER VALLEY

Yes

Yes

BIG ROCK POINT

No

4 BRAIDWOOD Yes
$\$ 10,000$

BROWNS FERRY

No

Yes

Yes

6 BRUNSWICK

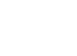

BYRON

Yes

Yes

callaway

CALVERT CLIFFS

CATAKBA

No

No

No

No

Yes

No

Yes

Yes *
$\$ 25,000$

11 CLINTON

12

COMANCHE PEAK

Yes

$$
\begin{gathered}
\text { Yes* } \\
\$ 120,000
\end{gathered}
$$

Yes

Yes

-

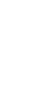

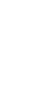
Rail Service

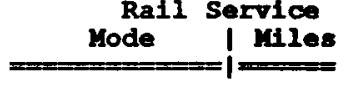

Onsite Rail: 1.0 Offsite Rail: 1.0

Onsite Rail: 1.8 Offsite Rail: 7.5 Road 13.4

Onsite Rail: 0.8 Offsite Rail: 0.1

$$
\text { Road } 9.0
$$

Onsite Rail: 0.5 Offsite Rail: 18.3 Total Rail: 18.8

Onsite Rail: 0.6 Offsite Rail: $\quad 7.1$
Total Rail: $\quad \mathbf{7 . 7}$ Road 15.1 Road 37.3

Onsite Rail: 6.3 Offsite Rail: 0.0 Total Rail: 6.3

Onsite Rail: 1.9 Offsite Rail: 0.1
Total Rail: $\quad \mathbf{2 . 0}$

Onsite Rail: 7.0 Offsite Rail: 7.0
Total Rall: 14.0 


\begin{tabular}{|c|c|c|c|c|c|c|}
\hline $\begin{array}{c}\text { S1te } \\
\text { Number }\end{array}$ & Site Name & $\begin{array}{l}\text { Onsite } \\
\text { Rail } \\
\text { service }\end{array}$ & $\begin{array}{l}\text { To Cask } \\
\text { Receiving } \\
\text { Area }\end{array}$ & $\begin{array}{l}\text { Offsite } \\
\text { Ra11 } \\
\text { Facility }\end{array}$ & $\begin{array}{c}\text { Access to Comm } \\
\text { Rail se } \\
\text { Mode } \\
\end{array}$ & $\begin{array}{l}\text { ercial } \\
\text { rvice } \\
\text { Miles }\end{array}$ \\
\hline 13 & COOK & $\begin{array}{c}\text { Yes* } \\
\$ 100,000\end{array}$ & Yes & - & $\begin{array}{l}\text { Onsite Rail: } \\
\text { Offsite Rail: } \\
\text { Total Rail: }\end{array}$ & $\begin{array}{l}1.2 \\
0.2 \\
1.4\end{array}$ \\
\hline 14 & COOPER & Yes & Yes & - & $\begin{array}{l}\text { Onsite Rail: } \\
\text { Offsite Rail: } \\
\text { Total Rail: }\end{array}$ & $\begin{array}{r}0.8 \\
26.0 \\
26.8\end{array}$ \\
\hline 15 & CRYSTAL RIVER & Yes & $\begin{array}{l}\text { Yes* } \\
\$ 80,000\end{array}$ & - & $\begin{array}{l}\text { Onsite Rail: } \\
\text { Offsite Rail: } \\
\text { Total Rail: }\end{array}$ & $\begin{array}{r}3.8 \\
75.0 \\
78.8\end{array}$ \\
\hline 16 & DAVIS-BESSE & Yes & Yes & - & $\begin{array}{l}\text { Onsite Rail: } \\
\text { Offsite Rail: } \\
\text { Total Rall: }\end{array}$ & $\begin{array}{l}0.8 \\
7.5 \\
8.3\end{array}$ \\
\hline 17 & DIABLO CANYON & No & No & Yes & Road & 19.1 \\
\hline 18 & DRESDEN & Yes & $\begin{array}{r}\text { Yes } \star^{11} \\
\$ 25,000\end{array}$ & - & $\begin{array}{l}\text { Onsite Rail: } \\
\text { Offsite Rail: } \\
\text { Total Rail: }\end{array}$ & $\begin{array}{l}0.5 \\
1.1 \\
1.6\end{array}$ \\
\hline 19 & DUANE ARNOLD & Yes & Yes & - & $\begin{array}{l}\text { Onsite Rail: } \\
\text { Offsite Rail: } \\
\text { Total Rall: }\end{array}$ & $\begin{array}{l}0.5 \\
3.0 \\
3.5\end{array}$ \\
\hline 20 & FARLEY & Yes & $\begin{array}{l}\text { Yes* } \\
\$ 45,000\end{array}$ & - & $\begin{array}{l}\text { Onsite Rail: } \\
\text { Offsite Rail: } \\
\text { Total Rail: }\end{array}$ & $\begin{array}{l}1.0 \\
3.8 \\
4.8\end{array}$ \\
\hline 21 & FERMI & $\begin{array}{l}\text { Yes* } \\
\$ 90,000\end{array}$ & $\begin{array}{l}\text { Yes* } \\
\$ 35,000\end{array}$ & - & $\begin{array}{l}\text { Onsite Rail: } \\
\text { Offsite Rail: } \\
\text { Total Rail: }\end{array}$ & $\begin{array}{l}0.8 \\
3.1 \\
3.9\end{array}$ \\
\hline 22 & FITZPATRICK & Yes & $\begin{array}{l}\text { Yes }^{\star} \\
\text { less than } \$ 10,000\end{array}$ & - & $\begin{array}{l}\text { Onsite Rail: } \\
\text { Offsite Rail: } \\
\text { Total Rail: }\end{array}$ & $\begin{array}{l}0.6 \\
3.6 \\
4.2\end{array}$ \\
\hline 23 & FORT CALHOUN & No & No & Yes & Road & 6.2 \\
\hline 24 & FORT ST. VRAIN & $\begin{array}{c}\text { Yes* } \\
\$ 100,000\end{array}$ & No & - & $\begin{array}{l}\text { Onsite Rail: } \\
\text { Offsite Rail: } \\
\text { Total Rail: }\end{array}$ & $\begin{array}{l}0.7 \\
6.3 \\
7.0\end{array}$ \\
\hline
\end{tabular}

* Upgrade would be needed - estimated cost indicated.

1. Dresden unit 1 would require $\$ 25,000$ to refurbish rail service to cask receiving area. Units 2 and 3 currently have usable rail service to cask receiving area. 
TABLLB 4.2 (continued)

Rail Shipment Capabilities

\begin{tabular}{|c|c|c|c|c|c|c|}
\hline $\begin{array}{c}\text { Site } \\
\text { Number } \\
==2=\end{array}$ & Site Name & $\begin{array}{c}\text { Onsite } \\
\text { Rail } \\
\text { Service }\end{array}$ & $\begin{array}{c}\begin{array}{c}\text { To Cask } \\
\text { Receiving } \\
\text { Area }\end{array} \\
\end{array}$ & $\begin{array}{l}\text { Offrite } \\
\text { Rail } \\
\text { Fac1lity }\end{array}$ & $\begin{array}{c}\text { Access to Coms } \\
\text { Rail S } \\
\text { Mode }\end{array}$ & $\begin{array}{l}\text { ercial } \\
\text { ivice } \\
\text { Miles }\end{array}$ \\
\hline 25 & GINNA & No & No & Yes & Road & 4.3 \\
\hline 26 & GRAND GULF & No & No & Yes & Road & 23.5 \\
\hline 27 & HADDAM NECK & No & No & Yes & Road & 13.6 \\
\hline 28 & HATCH & Yes & Yes & - & $\begin{array}{l}\text { Onsite Rail: } \\
\text { Offsite Rail: } \\
\text { Total Rail: }\end{array}$ & $\begin{array}{r}3.0 \\
11.0 \\
14.0\end{array}$ \\
\hline 29 & HUMBOLDT BAY & $\begin{array}{c}\text { Yes }^{\star} \\
\$ 100,000\end{array}$ & $\begin{array}{c}Y_{e s^{*}} \\
\$ 50,000\end{array}$ & - & $\begin{array}{l}\text { Onsite Rail: } \\
\text { Offsite Rail: } \\
\text { Total Rail: }\end{array}$ & $\begin{array}{l}0.1 \\
0.0 \\
0.1\end{array}$ \\
\hline 30 & INDIAN POINT & No & No & Yes & Road & 2.8 \\
\hline 31 & KEWAUNEE & No & No & Yes & Road & 10.0 \\
\hline 32 & LACROSSE & $\begin{array}{c}\text { Yes* } \\
\$ 100,000\end{array}$ & Yes & - & $\begin{array}{l}\text { Onsite Rail: } \\
\text { Offsite Rail: } \\
\text { Total Rail: }\end{array}$ & $\begin{array}{l}0.5 \\
0.0 \\
0.5\end{array}$ \\
\hline 33 & LASALLE & Yes & Yes & - & $\begin{array}{c}\text { Onsite Rail: } \\
\text { Offsite Rail: } \\
\text { Total Rail: }\end{array}$ & $\begin{array}{l}1.0 \\
5.9 \\
6.9\end{array}$ \\
\hline 34 & LIMERICK & Yes & $\begin{array}{c}\text { Yes* } \\
\$ 50,000\end{array}$ & - & $\begin{array}{l}\text { Onsite Rail: } \\
\text { Offsite Rail: } \\
\text { Total Rail: }\end{array}$ & $\begin{array}{l}0.5 \\
0.1 \\
0.6\end{array}$ \\
\hline 35 & MAINE YANKEE & Yes & Yes & - & $\begin{array}{l}\text { Onsite Rail: } \\
\text { Offsite Rail } \\
\text { Total Rall: }\end{array}$ & $\begin{array}{l}1.5 \\
0.0 \\
1.5\end{array}$ \\
\hline 36 & MCGUIRE & Yes & Yes & - & $\begin{array}{l}\text { Onsite Rail: } \\
\text { Offsite Rail: } \\
\text { Total Rall: }\end{array}$ & $\begin{array}{l}1.3 \\
2.6 \\
3.9\end{array}$ \\
\hline 37 & MILISTONE & $\begin{array}{c}\text { Yes } \\
\$ 100,000\end{array}$ & $\begin{array}{r}\text { Yes } \star^{1} \\
\$ 15,000\end{array}$ & - & $\begin{array}{l}\text { Onsite Rail: } \\
\text { Offsite Rail: } \\
\text { Total Rall: }\end{array}$ & $\begin{array}{l}0.5 \\
0.0 \\
0.5\end{array}$ \\
\hline
\end{tabular}

* Upgrade would be needed - estimated cost indicated. 1. Millstone units 1 and 2 currently have rail service to cask receiving area. Unit 3 could refurbish rail service to
cask receiving area for $\$ 15,000$. 
TABLE 4.2 (continued)

\begin{tabular}{ll}
$\begin{array}{c}\text { Site } \\
\text { Number }\end{array}$ & Site HaI \\
\hline 38 & MONTICELLO \\
39 & MORRIS \\
40 & NINE MILE POINT \\
41 & NORTH ANNA \\
42 & OCONEE \\
43 & OYSTER CREEK \\
44 & PALISADES \\
45 & PALO VERDE \\
46 & PEACH BOTTOM \\
47 & PERRY \\
48 & PILGRIM \\
49 & POINI BEACH \\
50 & PRAIRIE ISLAND \\
51 & QUAD CITIES \\
\hline 4
\end{tabular}

\section{Onsite \\ Rail}

Service

Yes

Yes

Yes

$$
\begin{array}{r}
\text { Yes } \star^{1} \\
\$ 125,000
\end{array}
$$

Yes

$$
\begin{gathered}
\text { Yes* } \\
\$ 50,000
\end{gathered}
$$

No

No

Yes

Yes
$\$ 10,000$

No

Yes*
$\$ 30,000$

No
No
Yes*
$\$ 25,000$
Yes

\section{Offite}

Facilit

Facility

Yes

Yes

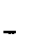

Yes

Yes Yes *
$\$ 10,000$

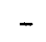

Yes

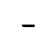

Yes

Yes

-

\section{Access to Commercial \\ Mode $=1$ Kiles}

Onsite Rail: 1.0 Offsite Rail: 0.0 Total Rail: 1.0

Onsite Rail: 0.1 Offsite Rail: 1.4

Onsite Rail: 1.6 Offsite Rail: $\begin{aligned} & 1.6 \\ & \quad 3.8\end{aligned}$

Onsite Rail: 0.8 Offsite Rail: $\quad 5.2$ Total Ra1l: 6.0

Road 7.6

Road 30.1

Road 12.7

Onsite Rail: 3.0 $\begin{array}{ll}\text { Offsite Rail: } & 2.2 \\ \text { Total Rail: } & \mathbf{5 . 2}\end{array}$ Road 34.5

Onsite Rail: 0.6 $\begin{aligned} \text { Offsite Rail: } & 3.5 \\ \text { Total Rail: } & \mathbf{4 . 1}\end{aligned}$ Road 12.4 Road 15.5

Onsite Rail: 0.4 Offsite Rail: 0.5 Total Rail: 0.9

Onsite Rail: 1.0 Offsite Rail: 0.0 rotal Rail: 1.0

* Upgrade would be needed - estimated cost indicated.

1. Nine Mile Point unit 1 currently has rail service to cask receiving area. Units 2 and 3 could refurbish rail service to cask receiving area for $\$ 22,500$. 
TABLE 4.2 (continued)

Rail Shipment Capabilities

\section{Site \\ Number \\ site Mame}

52 RANCHO SECO

53 RIVER BEND

54

ROBINSON

55

SAINT LUCIE

56

SALEM/HOPE CREEK

SAN ONOFRE

SEABROOK

SEQUOYAH

60

SHEARON HARRIS

61

SHOREHAM

62

\section{Onsite \\ Service}

Service

Yes

Yes*

$\$ 100,000$

Yes

No

No

Yes*
200,000

$$
\begin{gathered}
\text { Yes }^{\star} \\
\$ 25,000
\end{gathered}
$$

Yes*
$\$ 10,000$

Yes

No

Yes

\section{To Cask
Receiving}

Receiving

$x=====x$

Yes

Yes*
$\$ 75,000$

Yes

No

No

Yes

Yes*
$\$ 110,000$

Yes

Yes

No

Yes*

$\$ 85,000$
Offite

Facility

Facilit
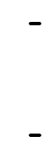

$-$

Yes

Yes

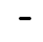$$
-
$$

Yes
Access to Commercial Rail Service
Mode I Kiles

Onsite Rail: 0.8 Offsite Rail: $\quad 0.2$ Total Rall: 1.0

Onsite Rail: $\quad 1.5$ Total Rail: $\mathbf{3 . 5}$

Onsite Rail: 0.2 Offsite Rail: 0.0

Onsite HHT: 0.2 Bargel: <10.0

Road 23.1

Onsite Rail: 0.7 $\begin{aligned} \text { Offsite Rail: } & 0.0 \\ \text { Total Rail: } & \mathbf{0 . 7}\end{aligned}$

Onsite Rail: 1.0 Offsite Rail: 13.0

Onsite Rail: $\quad 0.5$ Offsite Rail: $\quad 6.0$
Total Rail: $\quad 6.5$

Onsite Rail: 0.6 Offsite Rail:
rotal Rail: Road 10.0

Onsite Rail: 1.0 Offsite Rail: 12.0 Total Rail: 13.0 
TABLE 4.2 (continued)

Site

Number

Site Name

64 SURRY

65 SUSQUEHANNA

66

THREE MILE ISLAND

67 TROJAN

68

TURKEY POINT

7

71

72

73

VERMONT YANKEE

VOGTLE

WATERFORD

AIS BAR
63 SUMMER

Rail shipment

\section{Onsite \\ Service}

Service

Yes

No

Yes

Yes

Yes

No

WASHINGTON NUCLEAR PLANT

\section{To Cask}

Area

Rail

Facility

Access to Commercial

Mode I Yiles

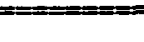

Yes

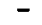

Onsite Rail: 2.5 $\begin{array}{ll}\text { Offsite Rail: } & 0.1 \\ \text { Total Rall: } & \mathbf{2 . 6}\end{array}$

Road 29.9

Onsite Rail: 1.2 Offsite Rail: $\quad 0.0$

Onsite Rail: 0.6 Offsite Rail: 0.0 Total Rail: 0.6

Onsite Rail: 0.1 Offsite Rail: 0.0

Onsite HнT: 0.3 Bargel: $<<30.0$
Total $:<30.3$

Onsite Rail: 0.4 Offsite Rail: 0.4 Total Rail: 0.8

Onsite Rail: 1.0 Offsite Rail: 13.0 Total Rail: 14.0

Onsite Rail: $\quad 0.6$ Offsite Rail: 13.1 Total Rall: 13.7

Onsite Rail: 0.5 Offsite Rail: 0.0 Total Rail: 0.5

Onsite Rail: 0.8 $\begin{aligned} \text { Offsite Rail: } & 6.5 \\ \text { Total Rail: } & 7.3\end{aligned}$
Yes

Yes 
TABLE 4.2 (continued)

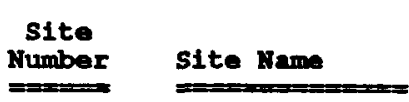

74 WOLF CREEK

75 YANKEE ROWE

$76 \quad$ ZION Rail Shipment Capabilities

\section{Onsite \\ To Cask}

Rail

Service

Yes*

$\$ 10,000$

Yes
Receiving

Area

Yes

No

Yes
Offiste

Ra11

Facility

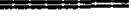

$-$

Yes
Access to Commercial Rail Service Mode I Miles

Onsite Rail: $\quad 0.7$ Offsite Rail: 11.3
Total Rail: 12.0

$$
\text { Road }
$$

Onsite Rail: 1.0 $\begin{aligned} \text { Offsite Rail: } & 0.1 \\ \text { Total Rail: } & 1.1\end{aligned}$ 
Twenty-three sites either never had rail service or the rail system serving the site is, for reasons discussed below, no longer viable, even if an identified upgrade was implemented. In order for these facilities to ship casks by rail, heavy-haul services to an operable rail line would be required. All of these sites are identified in Table 4.2 by the use of the word "Road" in the "Mode" column under "Access to Commercial Rail Service."

Another relevant consideration at sites that could make use of onsite rail systems is the presence of rail service to the cask receiving area. Of the 53 sites that could use onsite rail, 24 currently have rail service directly to the cask receiving area.

Another 25 sites could access rail from their cask receiving area if an identified upgrade were implemented to either the onsite rail system or a portion of the track leading to the cask receiving area. Fifteen of these 25 sites needed an upgrade to the portion of the rail servicing the cask receiving area. The average cost for the upgrades to the cask receiving areas was estimated to be $\$ 58,000$, and these upgrades were due to the need to either refurbish or install track from the termination of the onsite rail line to the cask receiving area. It should be noted, however, that an alternative to completing this upgrade would be to transfer casks within the site by HHT to a railcar. Three of the 15 sites, Dresden, Nine Mile Point and Millstone, have rail into the cask receiving area at some, but not all units at the site. Each would require an upgrade to access all units at the site; this upgrade averaged about $\$ 55,000$ per site. At four sites - Catawba, Fort St. Vrain, Trojan and WNP-2 - onsite rail capability exists but the cost to extend this into the cask receiving area would be greater than the $\$ 200,000$ limit adopted for the project. In these cases, onsite heavyhaul transportation to the usable portion of the site rail system would be required in order to transport rail casks to and from the cask receiving area.

For 21 of the 23 sites identified in the NSTI survey that do not have onsite rail service, an HHT vehicle route to an offsite rail facility was identified. This route was required to be capable of accommodating vehicles weighing up to 225 tons. The average length of the HHT routes for these sites is approximately 16 miles.

In most cases, the route leads to an offsite rail head or other formal transfer location such as a rail yard. In some cases a commercial rail siding was identified as the potential location for an offsite transfer point, primarily based on its proximity to the site. For two sites, it was determined that upgrade of the offsite rail facility would be needed prior to its use. Only minor refurbishment, averaging $\$ 15,000$, would be necessary.

For the remaining two of the 23 sites, Turkey Point and St. Lucie, a potential transfer facility was identified and assessed. However, a route was not available which could be used by an HHT vehicle for either site. In these two cases, rail/barge casks can only be shipped from the sites to an offsite rail facility by barge. 


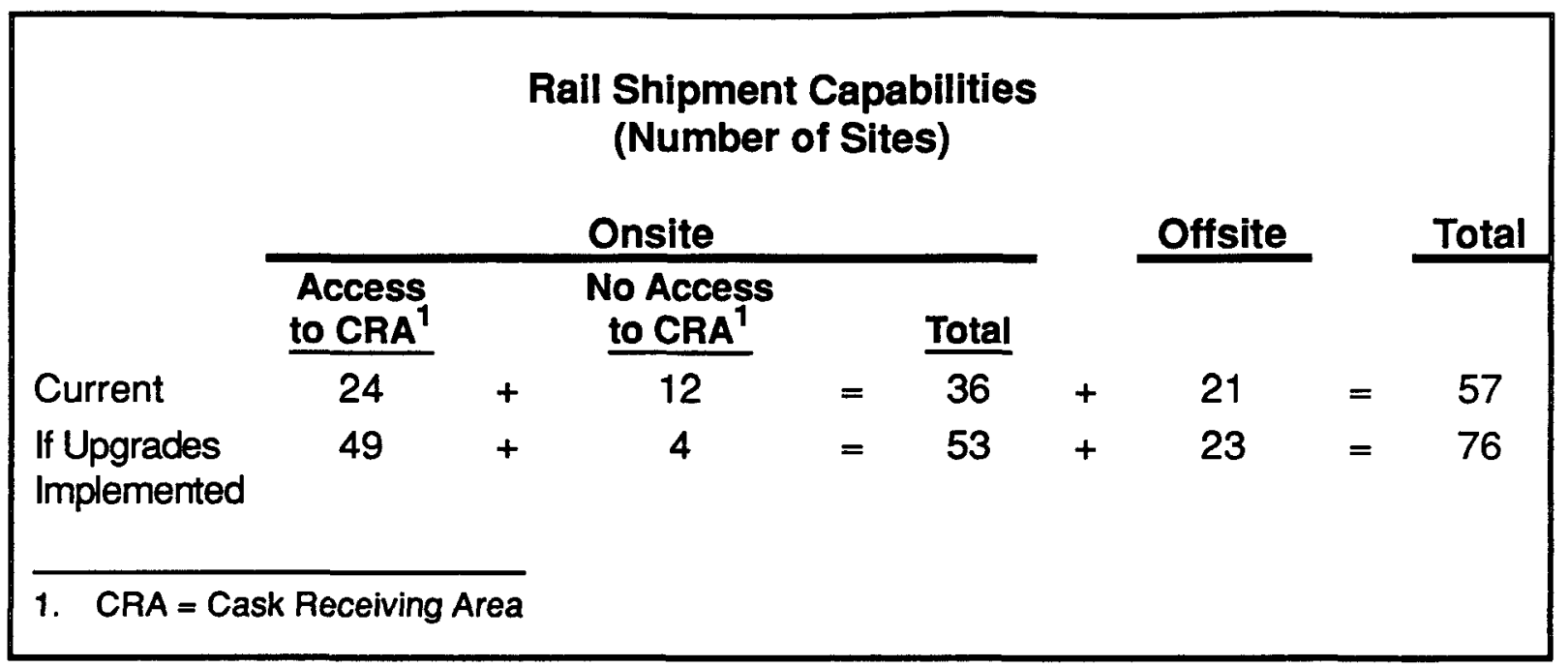

\subsection{Site Transportation Capability for Barge Shipments}

The potential capability for shipping by barge was assessed for each site surveyed. Table 4.3 presents the assessed barge shipment capability and identifies the navigable waterway associated with each site. For each site identified as having barge shipping capability, the associated heavy-haul distance is also shown.

Of the 76 sites included in the NSTI surveys, 17 currently have onsite barge facilities that are operational and could be used for the transportation of heavy loads. Each of these sites is located on or near a navigable waterway and has a dock area with sufficient space adjacent to it for loading/unloading operations. The average onsite distance to access an onsite barge facility is 0.5 mile.

An additional 24 sites have the potential to build or refurbish an onsite barge facility at a cost of less than $\$ 200,000$. As discussed in Section 3.0, the determination of usability was based on the estimated cost of the upgrade. If a barge facility were estimated to need upgrades in excess of $\$ 200,000$ for it to be usable, the site was not considered to have the potential for direct barge shipment from the site. However, the cost estimates given do not include costs for obtaining any required permits for the development of a barge capability. 


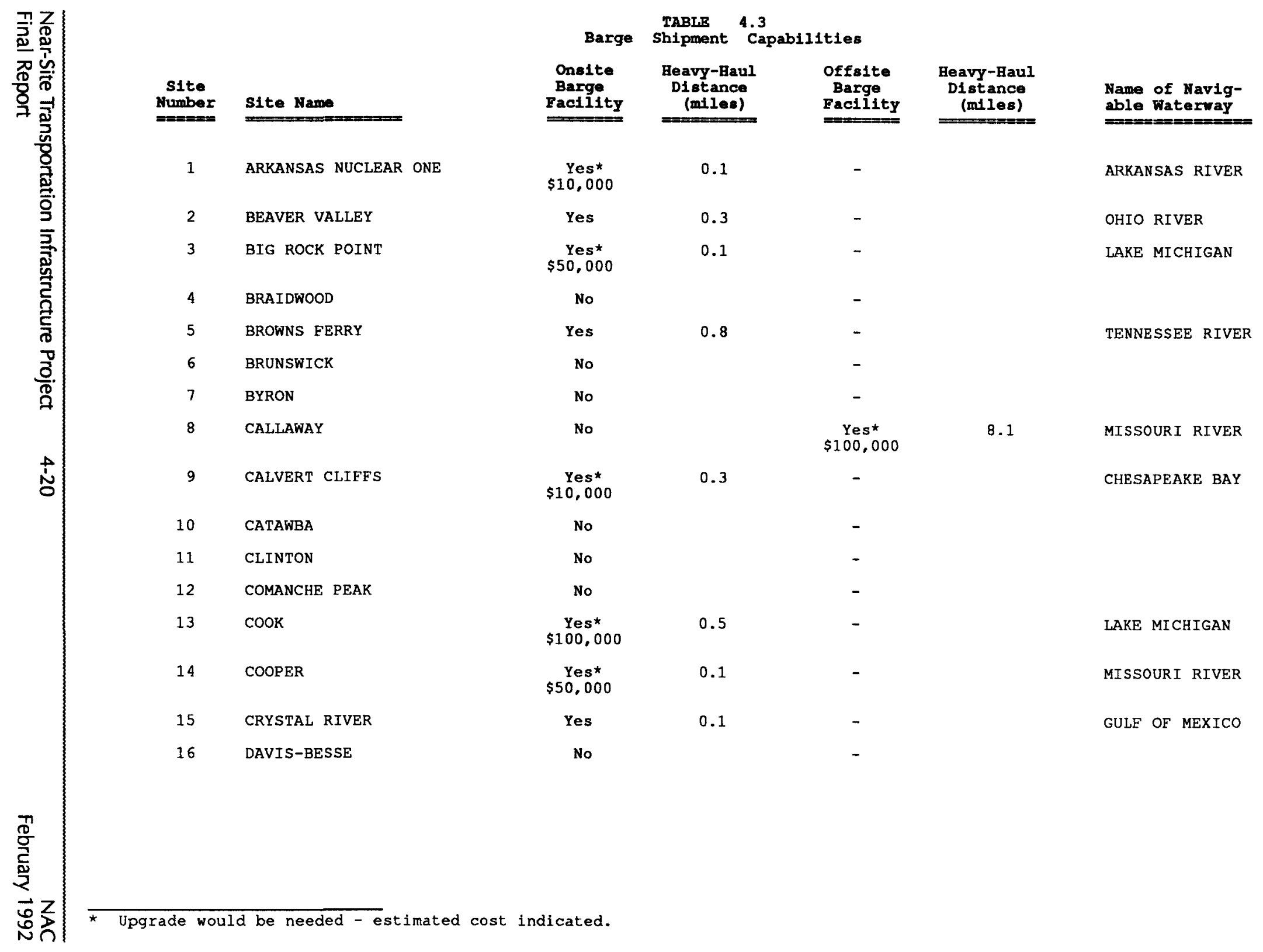




\begin{tabular}{|c|c|c|c|c|c|c|c|}
\hline ᄁᄁㅜㄹ & & & $\begin{array}{l}\text { IABLIE } \\
\text { Barge Shy }\end{array}$ & $\begin{array}{c}4.3 \\
\text { hipment }\end{array}$ & $\begin{array}{l}\text { ed) } \\
\text { ities }\end{array}$ & & \\
\hline 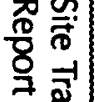 & $\begin{array}{c}\text { Site } \\
\text { Number } \\
====\end{array}$ & Site Name & $\begin{array}{c}\text { Onsite } \\
\text { Barge } \\
\text { Facility }\end{array}$ & $\begin{array}{c}\text { Heavy-Haul } \\
\text { Distance } \\
\text { (milles) } \\
\end{array}$ & $\begin{array}{l}\text { Offsite } \\
\text { Barge } \\
\text { Facility }\end{array}$ & $\begin{array}{c}\text { Beavy -Baul } \\
\text { Distance } \\
\text { (miles) } \\
\end{array}$ & $\begin{array}{l}\text { Name of Navig- } \\
\text { able Waterway }\end{array}$ \\
\hline 胥 & 17 & DIABLO CANYON & $\begin{array}{l}\text { Yes* } \\
\$ 50,000\end{array}$ & 0.6 & - & & PACIFIC OCEAN \\
\hline$\frac{9}{3}$ & 18 & DRESDEN & $\begin{array}{c}\text { Yes } \\
\$ 50,000\end{array}$ & 1.0 & - & & ILLINOIS RIVER \\
\hline $\mathbb{g}$ & 19 & DUANE ARNOLD & No & & - & & \\
\hline 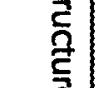 & 20 & FARLEY & less than $\$ 10,000$ & 0.9 & - & & CHATTAHOOCHEE RIVER \\
\hline D & 21 & FERMI & Yes & 0.4 & - & & LAKE ERIE \\
\hline 을. & 22 & FITZPATRICK & $\begin{array}{l}\text { Yes* } \\
\$ 50,000\end{array}$ & 0.2 & - & & LAKE ONTARIO \\
\hline & 23 & FORT CALHOUN & $\begin{array}{c}\text { Yes* } \\
\$ 50,000\end{array}$ & 0.1 & - & & MISSOURI RIVER \\
\hline 心 & 24 & FORT ST. VRAIN & No & & - & & \\
\hline & 25 & GINNA & No & & Yes & 2.0 & LAKE ONTARIO \\
\hline & 26 & GRAND GULF & Yes & 1.5 & - & & MISSISSIPPI RIVER \\
\hline & 27 & HADDAM NECK & $\begin{array}{c}\text { Yes* } \\
\$ 20,000\end{array}$ & 0.1 & - & & CONNECTICUT RIVER \\
\hline & 28 & HATCH & $\begin{array}{c}\text { Yes* } \\
\$ 10,000\end{array}$ & 0.2 & - & & ALTAMAHA RIVER \\
\hline & 29 & HUMBOLDT BAY & No & & - & & \\
\hline & 30 & INDIAN POINT & Yes & 0.4 & - & & HUDSON RIVER \\
\hline & 31 & KEWAUNEE & $\begin{array}{l}\text { Yes* } \\
\$ 25,000\end{array}$ & 0.1 & - & & LAKE MICHIGAN \\
\hline$\frac{1}{8}$ & & & & & & & \\
\hline 2 & e & & ndicated. & & & & \\
\hline
\end{tabular}




\begin{tabular}{|c|c|c|c|c|c|c|c|}
\hline ᄁᄁ & & & Barge & $\begin{array}{l}\mathbb{B} 4.3 \\
\text { Shipment }\end{array}$ & dies & & \\
\hline 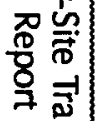 & $\begin{array}{c}\text { Site } \\
\text { Number } \\
=====\end{array}$ & Stte Name & $\begin{array}{c}\text { Onsite } \\
\text { Barge } \\
\text { Facility }\end{array}$ & $\begin{array}{c}\text { Heavy -Haul } \\
\text { Distance } \\
\text { (miles) } \\
\end{array}$ & $\begin{array}{l}\text { Offeite } \\
\text { Barge } \\
\text { Facility }\end{array}$ & $\begin{array}{c}\text { Heavy-Haul } \\
\text { Distance } \\
\text { (miles) } \\
\end{array}$ & $\begin{array}{l}\text { Name of Navig- } \\
\text { able Waterway }\end{array}$ \\
\hline 8 & 32 & LACROSSE & Yes & 0.2 & - & & MISSISSIPPI RIVER \\
\hline$\overline{0}$ & 33 & LASALLE & No & & - & & \\
\hline$\frac{5}{5}$ & 34 & LIMERICK & No & & - & & \\
\hline $\overrightarrow{\dot{B}}$ & 35 & MAINE YANKEE & Yes & 0.1 & - & & BACK RIVER \\
\hline 롱 & 36 & MCGUIRE & No & & - & & \\
\hline 들 & 37 & MILLSTONE & $\begin{array}{c}\text { Yesk } \\
\$ 20,000\end{array}$ & 0.1 & - & & LONG ISLAND SOUND \\
\hline 흠. & 38 & MONTICELLO & No & & - & & \\
\hline & 39 & MORRIS & No & & - & & \\
\hline & 40 & NINE MILE POINT & No & & - & & \\
\hline N & 41 & NORTH ANNA & No & & - & & \\
\hline & 42 & OCONEE & No & & - & & \\
\hline & 43 & OYSTER CREEK & Yes & 0.5 & - & & BARNEGAT BAY \\
\hline & 44 & PALISADES & $\begin{array}{c}\text { Yes } \\
\$ 100,000\end{array}$ & 0.5 & - & & LAKE MICHIGAN \\
\hline & 45 & PALO VERDE & No & & - & & \\
\hline & 46 & PEACH BOTTOM & No & & - & & \\
\hline & 47 & PERRY & $\begin{array}{c}\text { Yes } \\
\$ 100,000\end{array}$ & 0.1 & - & & LAKE ERIE \\
\hline & 48 & PILGRIM & $\begin{array}{l}\text { Yes* } \\
\$ 25,000\end{array}$ & 0.2 & - & & CAPE COD BAY \\
\hline I & & & & & & & \\
\hline (2) & e & ded & icated. & & & & \\
\hline
\end{tabular}




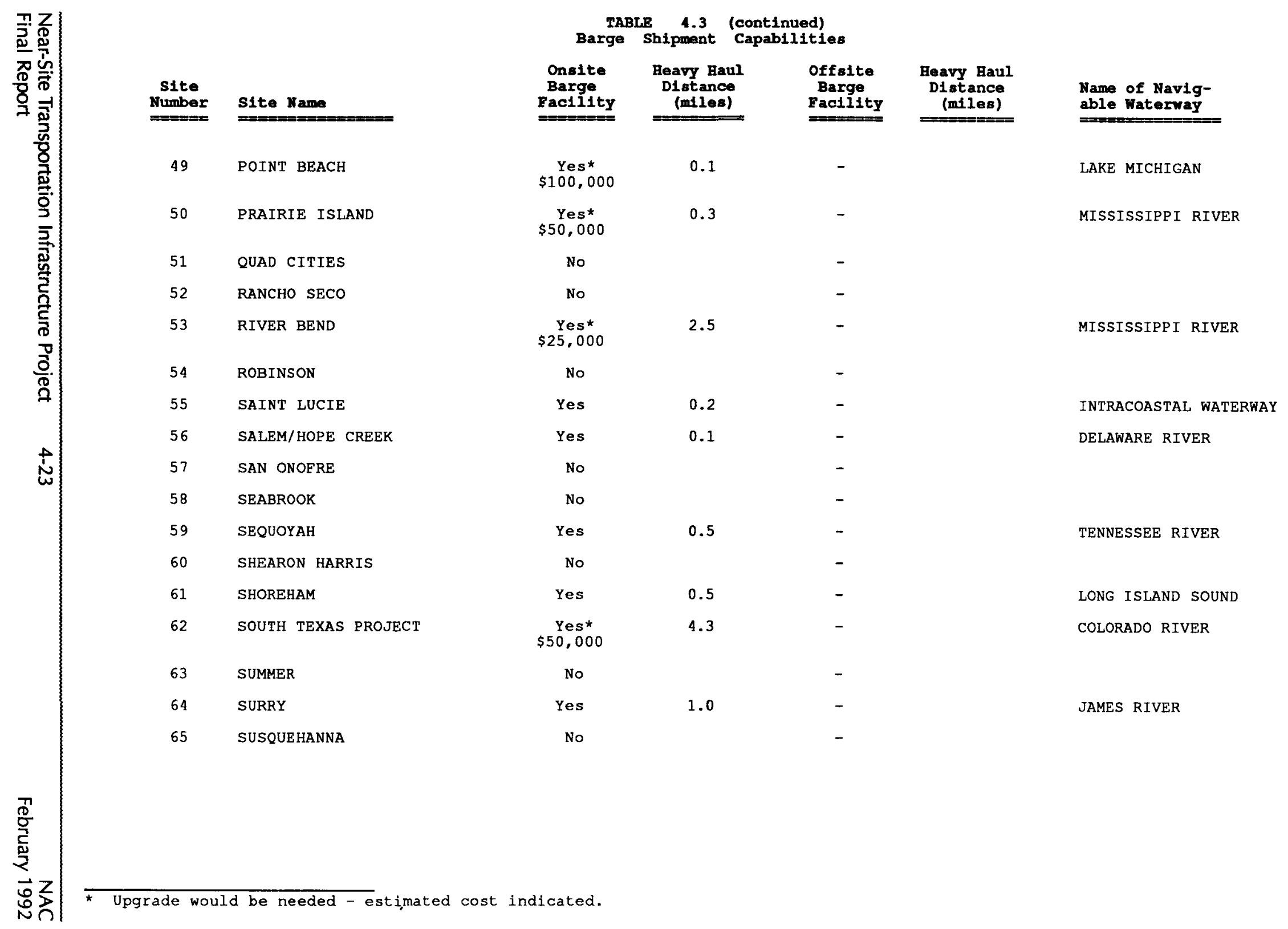




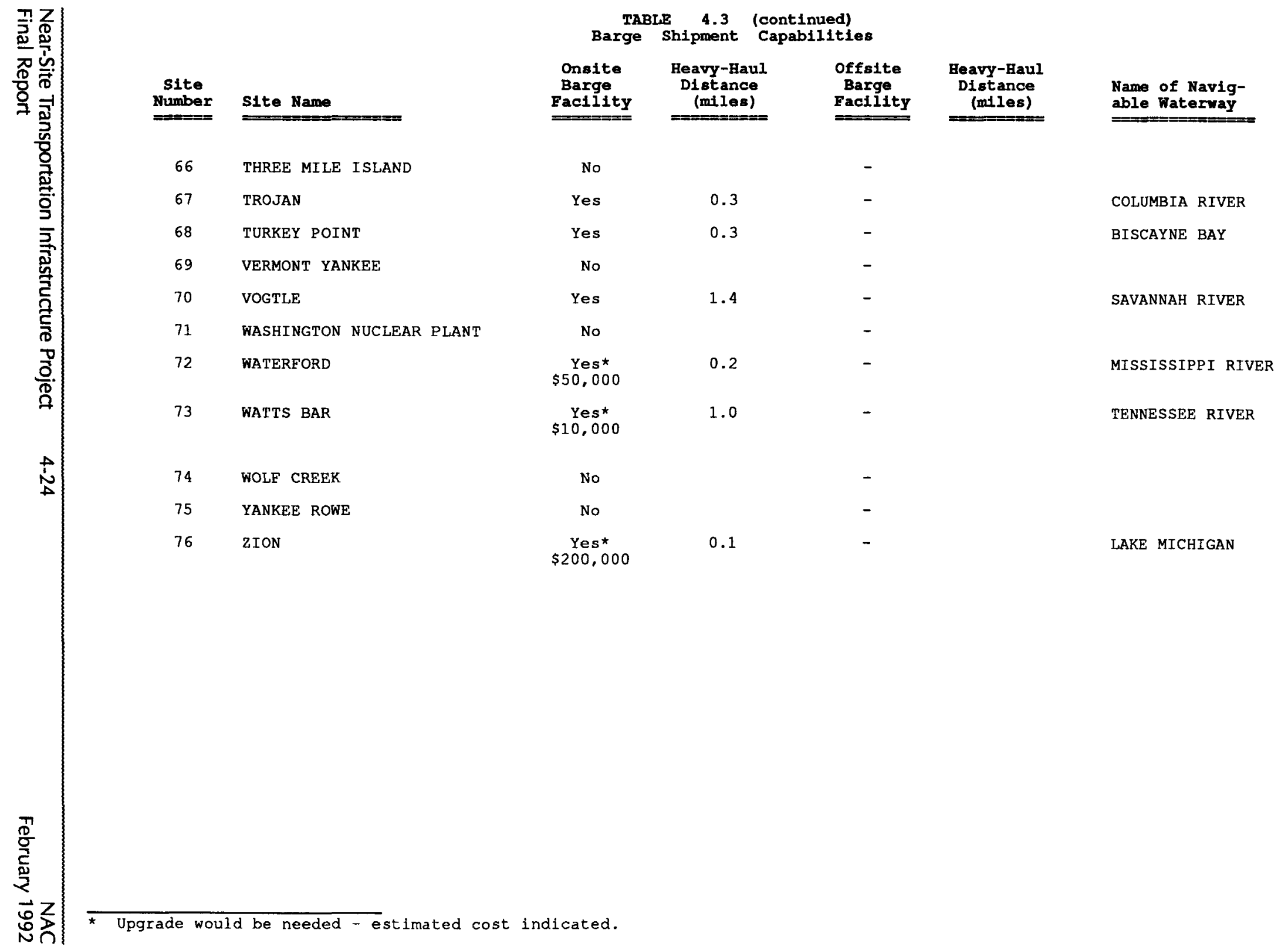




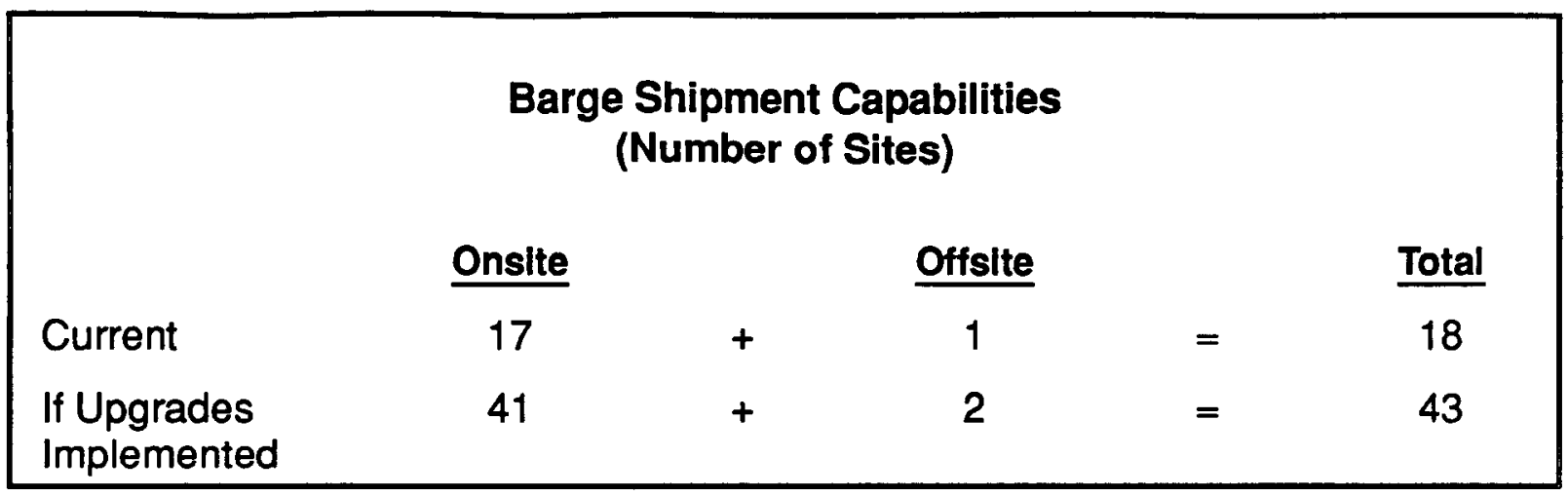

For the 24 sites that, if upgraded, could have operable onsite barge facilities, the average cost of these upgrades was estimated to be $\$ 50,000$. This work ranged from performing refurbishment such as minor dredging or installation of tie-offs to extensive dredging and loading/unloading area reconstruction.

The remaining $\mathbf{3 5}$ sites either are not located on or near a navigable waterway or are in locations where it would not be practicable to develop onsite barge capability for under $\$ 200,000$.

For those sites which did not have onsite barge or rail capability and which had an offsite barge facility within 25 miles of the site, a heavy-haul road route was identified and surveyed. The average length of the HHT route for these sites is approximately five miles. Callaway and Ginna were the only sites in this category. Only for Callaway was it determined that upgrading of the offsite barge facility would be needed prior to its use and the estimated cost of the upgrade was $\$ 100,000$. As with the HHT routes to rail facilities, the HHT routes to offsite barge facilities had to be capable of accommodating vehicles weighing up to 225 tons. The identified routes for both sites could accommodate loads up to this limit. 


\subsection{Summary of Site Transportation Capability and Conclusions}

Figure 4.3 summarizes the shipment capabilities of the 76 sites for each transportation mode. However, of the eight sites which could not currently ship casks by overweight trucks using Route $A$, four could do so using Route B. Thus, a total of 72 sites have the current capability to ship casks using overweight trucks.

The transportation infrastructure for each site was assessed to have the capability to ship casks on trucks which, when loaded, weigh no more than the 40-ton "legal weight" limit which applies in most states. At most sites, vehicles considerably in excess of this weight could also be shipped from the site by road.

The transportation infrastructure for each site was assessed as having the capability to ship rail/barge casks weighing more than 100 tons by at least one mode of transport. At many sites, casks of this type could be shipped by more than one mode. The availability of an onsite rail system provides the opportunity for direct rail shipment from 53 sites, in some cases if upgrades or extensions of the existing system are made. At 41 sites the availability of or potential for developing an onsite barge facility provides the opportunity for shipment from the site by barge. However, in only two cases (St. Lucie and Turkey Point) is this the only means of transportation from the site for rail/barge casks weighing over 100 tons.

During the site surveys, many utilities discussed their future use and maintenance plans for their transportation capabilities. As discussed above, all sites were assessed to have the capability to perform cask shipments by truck, and the utilities expect to be able to perform such shipments in the future. Rail and barge transportation plans are dependent on other factors and are addressed below.

Rail transportation plans vary greatly among the operations of the 76 sites included in the NSTI survey. No utility, however, expressed plans to abandon a rail system that was currently in place, although the maintenance programs for rail systems was based on their near-term projected use. At sites which expected to use the rail system frequently, utilities usually chose to maintain the rail system in a fully usable condition. At the sites operated by Carolina Power and Light, for example, plans to continue a program of spent fuel transshipments by rail have led the utility to maintain the sites' rail systems in a fully usable condition. Elsewhere, projections of less-frequent rail usage have led many utilities to maintain their rail systems on an as-needed basis. Finally, for many utilities that do not plan to use rail-based transportation, maintenance of the rail system has been deferred. Also, the continuing abandonment of track by the railroads has the potential to adversely impact the future prospects for rail service to some reactor sites. 
Barge transportation plans were very consistent among those sites with barge capability, mainly because they rarely made barge-based shipments. A regular maintenance program in these cases would not be cost-effective. Therefore, most utilities chose to maintain their barge facilities on an as-needed basis. 
Figure 4.3

\section{Transportation Capabilities By Mode}

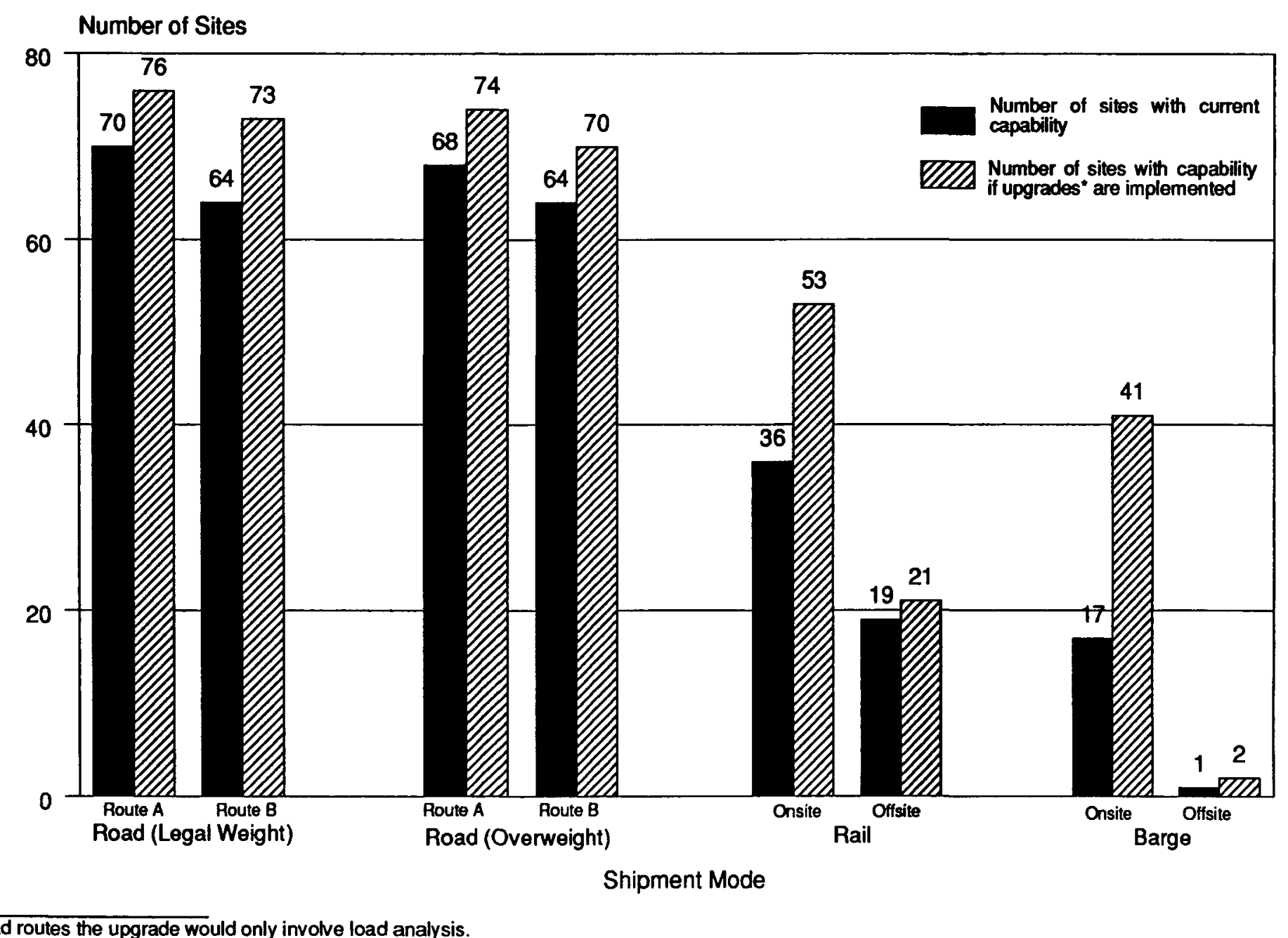

For some road routes the upgrade would only involve load analysis. 